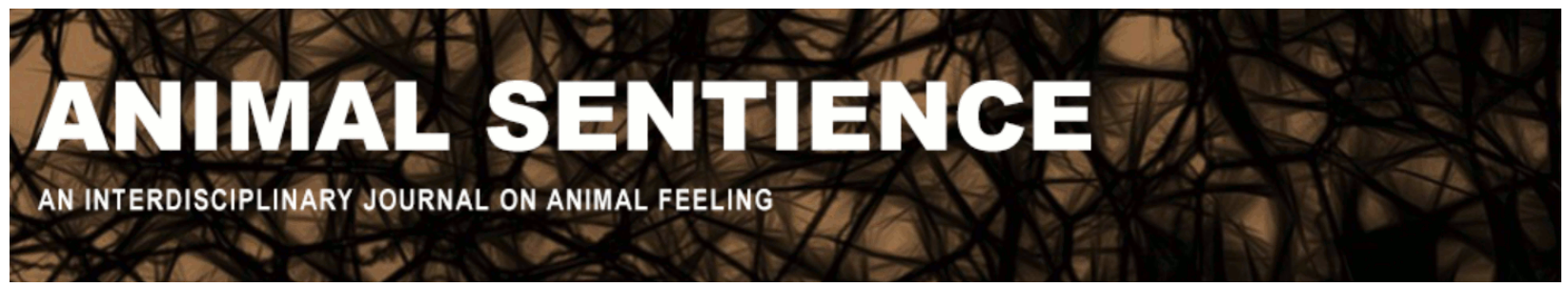

Kujala, Miiamaaria V. (2017) Canine emotions as seen through human social cognition. Animal Sentience 14(1)

DOI: $10.51291 / 2377-7478.1114$

Date of submission: 2016-06-27

Date of acceptance: 2017-07-08

(c)

This article has appeared in the journal Animal

Sentience, a peer-reviewed journal on animal

cognition and feeling. It has been made open access,

free for all, by WellBeing International and deposited

in the WBI Studies Repository. For more information,

please contact

wbisr-info@wellbeingintl.org.

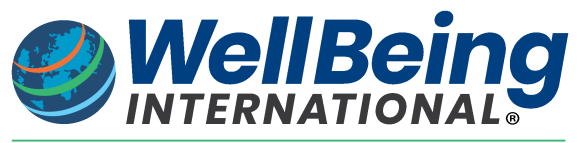

SOLUTIONS FOR PEOPLE, ANIMALS AND ENVIRONMENT 
Call for Commentary: Animal Sentience publishes Open Peer Commentary on all accepted target articles. Target articles are peer-reviewed. Commentaries are editorially reviewed. There are submitted commentaries as well as invited commentaries. Commentaries appear as soon as they have been reviewed, revised and accepted. Target article authors may respond to their commentaries individually or in a joint response to multiple commentaries.

Instructions: http://animalstudiesrepository.org/animsent/guidelines.html

\title{
Canine emotions as seen through human social cognition
}

\author{
Miiamaaria V. Kujala \\ Department of Equine and Small Animal Medicine, University of Helsinki, Finland \\ Department of Neuroscience and Biomedical Engineering, Aalto University, Finland
}

\begin{abstract}
It is not possible to demonstrate that dogs (Canis familiaris) feel emotions, but the same is true for all other species, including our own. The issue must therefore be approached indirectly, using premises similar to those used with humans. Recent methodological advances in canine research reveal what dogs experience and what they derive from the emotions perceptible in others. Dogs attend to social cues, they respond appropriately to the valence of human and dog facial expressions and vocalizations of emotion, and their limbic reward regions respond to the odor of their caretakers. They behave differently according to the emotional situation, show emotionally driven expectations, have affective disorders, and exhibit some subcomponents of empathy. The canine brain includes a relatively large prefrontal cortex, and like primates, dogs have a brain area specialized for face perception. Dogs have many degrees of emotion, but the full extent of dog emotions remains unknown. Humans are a socially minded species; we readily impute mind and emotion to others, even to vegetables or rocks. Hence the experimental results need to be analyzed carefully, so the emotional lives of dogs are accurately estimated.
\end{abstract}

Keywords: Canis familiaris, domestic dog, emotion, psychology, social cognition, comparative cognition, neuroscience

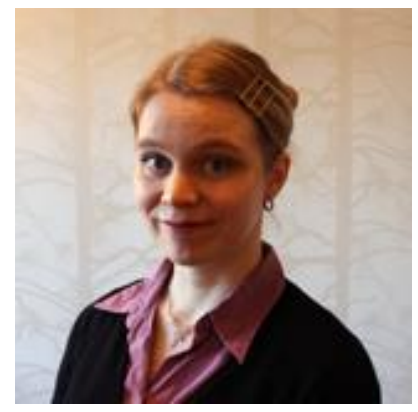

Miiamaaria V. Kujala (Saarela) is a researcher in comparative cognition at the University of Helsinki, Faculty of Veterinary Medicine, Department of Equine and Small Animal Medicine, Helsinki, Finland; and Aalto University School of Science, Department of Neuroscienceand Biomedical Engineering, Espoo, Finland. A social cognitive neuroscientist, her current research interests are social cognition and emotional experience in dogs, non-invasive brain research across species, and human perception and interpretation of animals.

http://orcid.org/0000-0002-1377-2187 


\section{Introduction}

Dogs are our age-old domesticated companions. Darwin (1872) considered dogs as a comparative example in his work on emotional expression across species. Sharing the living environment with us, dogs have developed remarkable social skills in inter-species communication (for the original articles, see Hare et al. 1998, Soproni et al. 2001, Call et al. 2003, Miklósi et al. 2003, Kaminski et al. 2009). Thus, it is no surprise that we have inherent interest in understanding dog experience, behavior, and cognition. However, proving that someone experiences something is an impossibility because experiences are subjective (Nagel 1974). We can never know that another person experiences the same thing as us. There are always subtle differences in the underlying psychology and physiology, although the larger-scale responses may be similar within a species. How, then, can we know anything about the inner lives of other species such as our companion dogs?

In human emotion research, "emotion" and "feeling" are often separated because emotion can be targeted for objective experimental study through behavioral and neurophysiologic observations, whereas feeling is subjective: What the emotion feels like and how it is interpreted by the subject can only be inferred indirectly. We can detect the behavioral and physiological correlates of both my happiness and your happiness, but they can be felt and interpreted very differently by each of us.

In this work, the topic of canine emotions is approached using the framework of Anderson and Adolphs (2014). They argue that the capacity for emotion can exist across phylogeny, but emotions may consist of a different set of parallel behavioral, somatic, physiological, and cognitive responses in different species. We begin by considering the effect of the human viewpoint. Canine emotions are examined both behaviorally and biologically, with a brief review of the neural basis for primary emotions and the respective structures in the dog brain. The neural basis for secondary emotions is also reviewed, followed by a discussion of the current research on dogs. Long-term moods and comparative aspects are also considered. The ultimate purpose of this target article is to stimulate discussion about the nature and extent of dog emotions and the need for this new field of research, as well as to provide groundwork for the approach from various scientific disciplines.

One of the difficulties in considering emotional states in dogs is the inconsistency in terminology across studies. Avoiding anthropomorphic terms has left many canine affective phenomena without a standardized terminology. Different researchers have used different terms for the same phenomenon, or similar terms for separate phenomena. This review attempts to integrate results across studies and disciplines.

\section{Human social cognition affects perception of dog emotional states}

The existence of emotions in dogs and the perception of dog emotions by the human caretakers are separate issues. Everyday life presents many possibilities for humans to misinterpret the mind behind a dog's behavior. For example, guardians may misinterpret the dog's affective state in separation-related anxiety (see Mendl et al. 2010a). According to the three-factor theory of anthropomorphism (Epley et al. 2007), behavioral interpretations that are often valid with other humans are also easily attributed to non-human animals such as 
dogs. Thus, human, biologically tuned social perception is the starting point, as it filters our understanding of dog emotions.

People believe that animals such as dogs experience emotions (Morris et al. 2008, Morris et al. 2012, Walker et al. 2014). Humans are also quite consistent in classifying dogs' emotional behavior in different contexts (Pongrácz et al. 2005, Tami \& Gallagher 2009, Walker et al. 2010, Buckland et al. 2014, Faragó et al. 2014, Lakestani et al. 2014). Humans friendly dog behavior most easily recognize, whereas aggression and fear are more difficult to identify (Tami \& Gallagher 2009, Wan et al. 2012, Mirkó et al. 2013, Lakestani et al. 2014) - especially by children (Meints et al. 2010, Lakestani et al. 2014). Prior experience of dog behaviour and training, rather than mere guardianship, enhances the interpretation of canine behaviour from the whole-body cues (Kujala et al. 2012, Wan et al. 2012).

Although emotions are visible throughout dog bodily cues, human attention is generally drawn to the faces of both humans (Johnson et al. 1991) and dogs (Quinn et al. 2009). Humans can classify a dog's emotional valence (positivity-negativity) from the face irrespective of prior experience with dogs (Bloom \& Friedman 2013, Schirmer et al. 2013). They can distinguish happiness (88\% of the time) and anger/aggressiveness (70\%) from a dog's face, but discrimination of other discrete expressions is less reliable (fear: 45\%, sadness: $37 \%$, surprise: $20 \%$, and disgust: $13 \%$; Bloom \& Friedman 2013).

Perception of others is affected by many factors in the human mind. The human social mind is equipped with a presupposition of intentionality (for reviews, Blythe et al. 1999, Scholl \& Tremoulet 2000, Urquiza-Haas \& Kotrschal 2015), from which anthropomorphism can arise. Attributing intentionality or other human characteristics to non-living things is strengthened by personal connection (Kiesler et al. 2006), and mental attribution is found in people's descriptions of rocks (Kiesler \& Kiesler 2005), computers (e.g., Nass et al. 1994), animations (Chaminade et al. 2007), robots (Gazzola et al. 2007, Imamura et al. 2015, Martini et al. 2016), or even vegetables (Vaes et al. 2016). Humans also project their views of themselves onto dogs much as they do with conspecifics, and their perceptions of dogs are similarly affected by stereotypes (Kwan et al. 2008). Thus, humans easily attribute mental and emotional states to companion dogs, and human interpretation of canine emotions is filtered by human psychological characteristics (Kujala et al. 2017).

Humans can also deny humanity in other humans (for reviews, Leyens et al. 2000, Haslam 2006). They consistently attribute more complex emotions to their in-group than out-group members (see Leyens et al. 2000). In a human brain imaging study, the observation of images of extreme out-group members (such as drug addicts or the homeless) failed to produce the medial prefrontal cortex activation connected with social cognition (Harris \& Fiske 2006). Thus, the human mind is affected by various social factors, with the judgments sometimes representing more the judge's own ideology than the reality. Likewise, when humans attempt to decipher canine emotions, dog guardians can underestimate their dogs' aggressiveness (Mirkó et al. 2013).

Attributing minds to others is innate in humans, and the human brain appears remarkably flexible regarding the source of the other mind. Human empathy generalizes to other species (Ascione 1992, Paul 2000, Taylor \& Signal 2005, Norring et al. 2014, Westbury Ingham et al. 2015, Kujala et al. 2017) and affects our interpretation of dog behavior (Meyer \& Forkman 2014, Meyer et al. 2014). Empathy (Westbury Ingham et al. 2015) and the attribution of mental states (Harrison \& Hall 2010) to non-human animals varies with their 
phylogenetic relatedness to humans. Mental attribution to both human and non-human species is connected to the temporoparietal junction associated with human theory-of-mind abilities (Cullen et al. 2014). Human brain responses to dogs can also be strikingly similar to responses to human conspecifics, whether observing dogs' facial expressions (Spunt et al. 2016), pain (Franklin et al. 2013), or social interaction (Kujala et al. 2012). Human brains seek other minds and emotions, and dog emotional behaviour is filtered through the same machinery.

\section{Neural support for the basic (primary) canine emotions}

It is generally agreed that basic emotional states such as anger, happiness, and fear are evolutionarily adaptive (Ekman 1992, Izard 1992, Panksepp 1998, Plutchik 2001), and they have universal facial expression patterns in humans (Ekman \& Friesen 1971). Basic emotional states are associated with neural structures within the limbic system and its connections to the neocortex in mammals (Damasio 1994; LeDoux 1996; Rolls 1999). Specific basic emotions are associated with specific chemical neurotransmitter balance in the brain (Panksepp 1998).
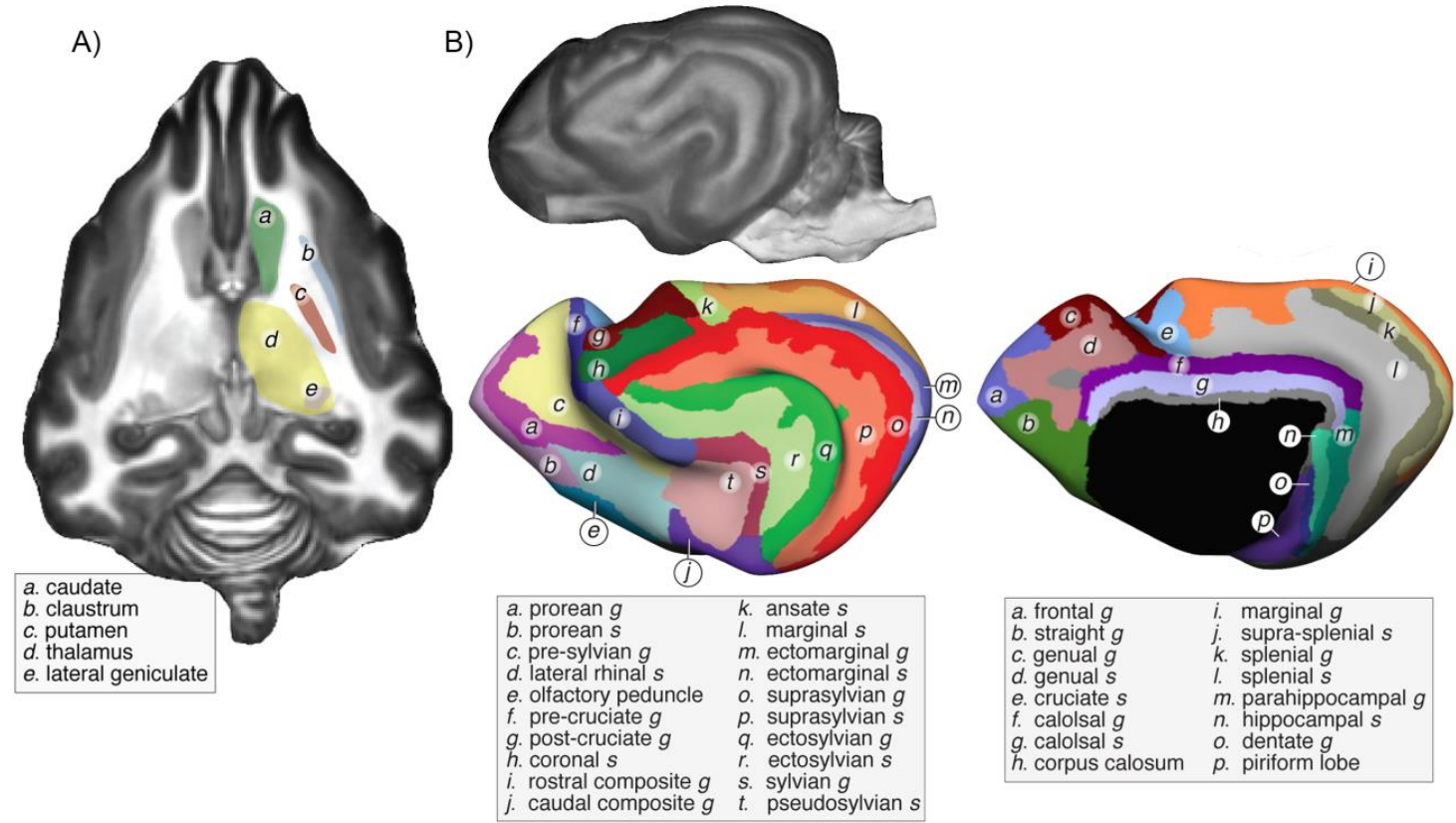

Figure 1. Key areas of the dog brain. (A) Some key subcortical areas shown on the axial magnetic resonance imaging slices (dog's nose pointing upwards; top = anterior, bottom = posterior, left $=$ left hemisphere, and right = right hemisphere) and (B) the cortical surface of the dog brain, with the sulci opened and the nomenclature overlaid below. The cortical surface is shown laterally from the left hemisphere (dog's nose pointing left; left = anterior, right = posterior, top = dorsal, and bottom = ventral); the image has been magnified with standard digital image processing to show the gyri and sulci. Modified, under the terms of the Creative Commons Attribution License, from figures http://dx.doi.org/10.1371/journal.pone.0052140.g002 and http://dx.doi.org/10.1371/journal.pone.0052140.g003 (Datta et al. 2012). 
The domestic dog, as a member of mammalian order Carnivora and the Caninae family, has a brain that includes all the major structures and connections supporting basic emotional functions (Jensen 2007, de Lahunta \& Glass 2009, Evans \& de Lahunta 2013). Dog brains include, bilaterally, the limbic system with the nucleus accumbens; the amygdala with its sensory and cortical connections; the cingulate cortex; and the sensory-motor cortices and the insula, deep within the pseudosylvian fissure (in humans, the Sylvian fissure occupies the topologically equivalent position). Dogs also have a relatively large prefrontal cortex that is not directly associated with motor functions (see Figure 1, Palazzi 2011, Datta et al. 2012, Evans \& de Lahunta 2013).

The corresponding structures in humans have been studied extensively in recent decades regarding their roles in social and emotional function (for reviews, see e.g., Bush et al. 2000, Damasio et al. 2000, Adolphs 2002, Leppänen \& Nelson 2009, Etkin et al. 2011, Schilbach et al. 2013). For dogs, the research is more scattered. Some dog brain function is also inferred from neurological experiments with cats (Felis catus) and the homologues between the brain anatomies of the two species. Many functions of the subcortical nuclei (e.g., the septal area or hypothalamus) and the finer neurophysiologic details, as well as visual cortical organization, are inferred from cat studies (King 1987, de Lahunta \& Glass 2009, Sjaastad et al. 2010). Utilization of the methodology for studying human brain function has facilitated the study of dog brains. A recent study showed that dogs' nucleus accumbens is activated by the odor of familiar humans, highlighting the possibilities of methodological advances in examining dog emotions (Berns et al. 2015).

Dog and human brains also have important differences. The association areas (brain areas not directly responsible for sensomotor functions) cover about $20 \%$ of the dog neocortex but $85 \%$ of the human neocortex (Evans \& de Lahunta 2013). The rhinencephalon, devoted to processing olfactory signals, covers a relatively large area in dog brains (Evans \& de Lahunta 2013). The existence of limbic and cortical structures in dogs is consistent with having the basic emotions, although dogs' qualia - what it feels like to be a dog (Nagel 1974) - no doubt differ from our own.

\section{Emotional reactivity and affective-behavioral disorders in dogs}

Research on dog emotions has traditionally concentrated on the problems dog behavior causes for the human guardians, which is why we know more about dog fear and aggression. Dog emotionality has been studied to predict general emotional reactivity (Goddard \& Beilharz 1986, Sforzini et al. 2009), aggression (Netto \& Planta 1997, van den Berg et al. 2003, van der Borg et al. 2010), behavioral disorders (van der Borg et al. 1991), and differences among dog breeds (Scott \& Fuller 1965) from puppies to adulthood. Dog aggressiveness is tested by presenting provocative stimuli, such as an unfamiliar barking dog (Netto \& Planta 1997, van den Berg et al. 2003) or staring the dog in the eyes (Sforzini et al. 2009). Guardian questionnaires are also used (Netto \& Planta 1997, Hsu \& Serpell 2003, Duffy et al. 2008). Similarly, testing a dog's fearfulness can include presenting a sudden loud noise, a novel object, a falling bag, or a gunshot (Melzack 1952, Beerda et al. 1998, King et al. 2003, Hydbring-Sandberg et al. 2004, Morrow et al. 2015). 
Both fearful and aggressive behaviors in dogs are associated with some physiological or autonomic responses. Stimuli eliciting fearful behavior in dogs increase their cortisol (Beerda et al. 1998, King et al. 2003, Hydbring-Sandberg et al. 2004, Dreschel \& Granger 2005, Morrow et al. 2015) or progesterone levels (Hydbring-Sandberg et al. 2004), heart rates (King et al. 2003, Hydbring-Sandberg et al. 2004, Ogata et al. 2006), and body temperatures (Ogata et al. 2006). Aggressive behaviors are associated with reduced serotonergic function (Reisner et al. 1996).

The most common affective-behavioral clinically treated disorders in dogs are related to fearful or aggressive behavior and may be induced by separation anxiety, noise sensitivity (for review, Sherman \& Mills 2008), and dominance/competitive aggression (see e.g., Beaver 1983, Wright \& Nesselrote 1987, Cameron 1997, Reisner 1997, Haug 2008). Treatments for these conditions usually include behavior modification, often combined with neuropharmacological medication as in human psychiatric disorders (Overall 2000).

Taken together, aggression and fear are the most studied emotions in dogs, but research on other emotional states is scarce. An exception among the positive emotions is dog play behavior, which is well-documented (Bekoff 1974a, Bekoff 1974b, Bekoff 1995, Rooney et al. 2000, Horvath et al. 2008, Ward et al. 2008, Horowitz 2009a, Palagi et al. 2015).

\section{Production and perception of facial expressions}

Faces and facial expressions convey delicate and meaningful information about emotional states to conspecifics in humans (for reviews, Adolphs 2002, Calder \& Young 2005, Hari \& Kujala 2009, Leppänen \& Nelson 2009) as well as in many non-human species (for reviews, Tate et al. 2006; Leopold \& Rhodes 2010). Facial expressions of emotion in dogs were discussed by Darwin (1872); they characterized in great detail since the 1960s, noting similarities in the emotional expressions for aggression and happiness between dogs, other carnivores, and primates (Bolwig 1964, Fox 1970). A precise coding of human facial expressions based on the movement of facial muscles - a facial action coding system (FACS) - was developed in the 1970s (Ekman \& Friesen 1978). The system has since been applied to many other primate species (Vick et al. 2007, Parr et al. 2010, Waller et al. 2012, Caeiro et al. 2013), horses (Equus caballus, Wathan et al. 2015), cats (http://www.catfacs.com/), and dogs (Waller et al. 2013). Deviating from the human-FACS, the non-human-FACS often includes the movement of ears.

Behavioral and brain responses during the perception of facial expressions have been studied in non-human primates and sheep for decades (see Tate et al. 2006). As a second nonprimate species after sheep (Kendrick \& Baldwin 1987), dogs have been shown to possess a distinguishable face-processing region in the temporal cortex, separating brain responses to faces from the responses to objects (Figure 2) (Dilks et al. 2015, Cuaya et al. 2016). The response profiles are roughly comparable with those of the human fusiform face area (Kanwisher et al. 1997), although the cortical region seems to be more variable in dogs. In humans, face processing continues from the fusiform to the inferotemporal cortex and the superior temporal sulcus, with the extraction of identity- and emotion-specific information (for review, Haxby et al. 2000). 

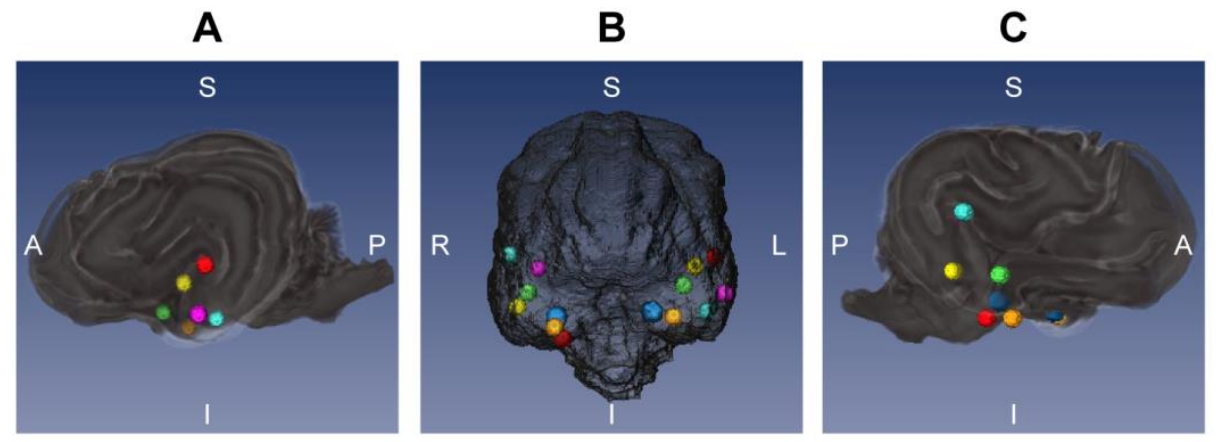

Figure 2. Stronger brain responses from dogs for faces versus objects. Images show the focus of brain activation during non-invasive functional magnetic resonance imaging in seven dogs for faces versus objects with contrast, overlaid on a digitally produced glass brain to reveal foci located within the sulci. (A) Lateral view from left hemisphere, (B) rostral view from front, and (C) lateral view from right hemisphere. $\mathrm{A}=$ anterior, $\mathrm{P}=$ posterior, $\mathrm{S}=$ superior (or dorsal), $\mathrm{I}=$ inferior (and ventral), $\mathrm{L}=\mathrm{left}$, and $\mathrm{R}=$ right. Modified, under the terms of the Creative Commons Attribution License, from figure http://dx.doi.org/10.1371/journal.pone.0149431.g005 (Cuaya et al. 2016).

While direct information on dogs' brain processing of emotional expressions is missing, a growing body of behavioral and eye-tracking research supports the ability of dogs to distinguish negative and positive facial expressions in both humans and dogs, and to respond appropriately according to the valence of faces (Nagasawa et al. 2011, Racca et al. 2012, Müller et al. 2015, Barber et al. 2016, Somppi et al. 2016) (Figure 3).

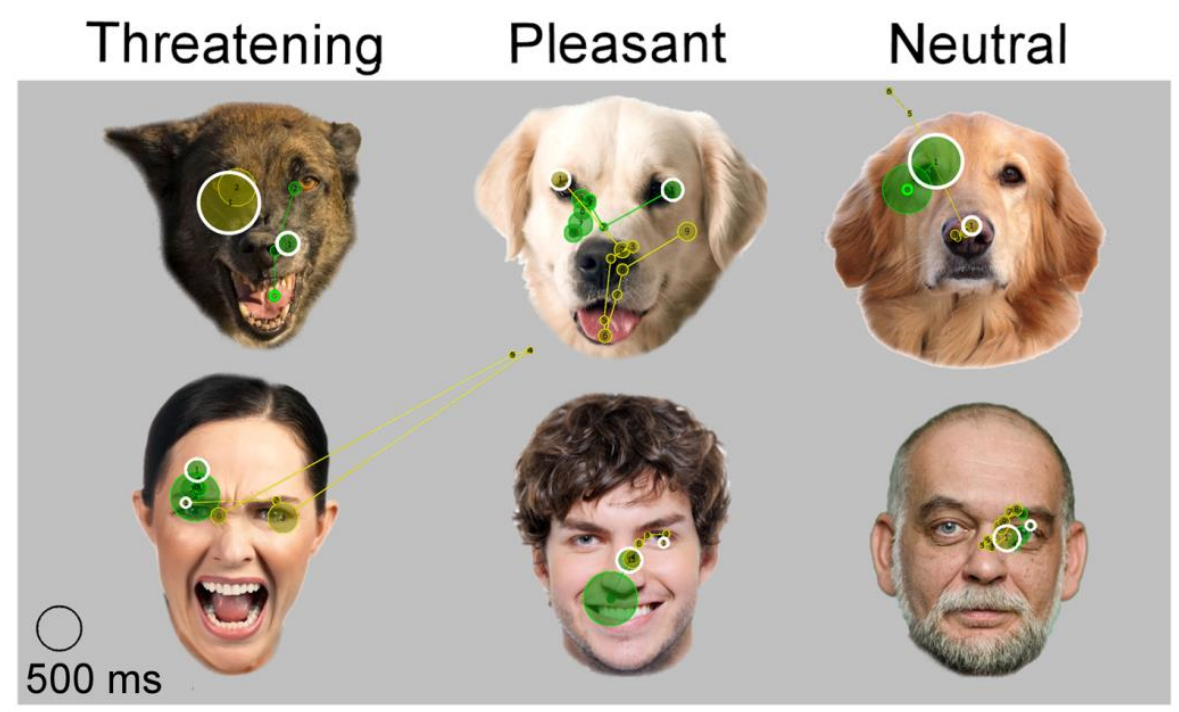

Figure 3. Gaze fixations (circles) and scanning paths (lines between the circles) of two dogs (shown in light and dark green) for facial expressions of dogs and humans. White circles represent the targets of the first fixations; dogs tend to gaze first into the eyes of both humans and dogs. Figure from http://dx.doi.org/10.1371/journal.pone.0149431.g005 (Somppi et al. 2016), reprinted under the terms of the Creative Commons Attribution License. 
Dogs associate emotional vocalizations of both humans and dogs with the corresponding facial expressions, showing multisensory processing of emotional expressions (Albuquerque et al. 2016). Like human infants, dogs use human emotional expressions for social referencing, as a source of approach/avoid information for novel objects (Merola et al. 2012b, Merola et al. 2012a, Buttelmann \& Tomasello 2013, Merola et al. 2014, Turcsán et al. 2015). Furthermore, they appear to generalize the valence information of facial expressions across human individuals (Müller et al. 2015, Somppi et al. 2016) rather than responding only to guardians' expressions - in contrast to cats, who respond mainly to the valence of their guardians' facial expressions (Galvan \& Vonk 2016).

Human cross-cultural studies could provide some useful clues for studying emotions in dogs. The basic emotions are remarkably similar around the world (Ekman \& Friesen 1971). Facial expressions and their recognition, situations provoking emotions, and the organization of emotions on the valence-arousal dimensions are consistent across cultures (Shaver et al. 1992). However, the perception of emotional intensity differs across cultures (Ekman et al. 1987), and the decoding and encoding of emotion in the cultural in-group appears more accurate (for meta-analysis, Elfenbein \& Ambady 2002). Similarly to the cultural differences in humans, differences in breeds or environment may affect the expression or perception of emotion in dogs (for review, Mehrkam \& Wynne 2014).

It appears unquestionable that dogs can both produce and process emotions through facial expression, but the question is to what extent? One remaining question concerns what part of recognizing human facial expressions by dogs is innate and what is learned through association and experience. Also, the research addressed mainly the positive-negative valence information of faces rather than the more diverse, discrete expressions of emotion (e.g., happiness, sadness, surprise, fear, disgust, anger: Ekman \& Friesen 1971), so information on dogs' ability to discriminate or respond to discrete expressions of emotion is lacking. Are there universal facial expressions of emotion in dogs as there are in humans (Ekman \& Friesen 1971) — and if so, what are they?

\section{Fundamental basis for secondary (social) emotions}

Secondary emotions - generated through the interpretation of social situations and requiring some sense of another's mind - are less likely than basic (primary) emotions to be attributed to dogs by people, but 22 to $94 \%$ of people believe that dogs do have secondary emotions such as shame or guilt (Morris et al. 2008, Morris et al. 2012). As adult humans, we effortlessly attribute secondary emotions to other people. Without knowledge of the differences among minds across species, we can just as easily attribute the emotions to nonhumans, including dogs. However, dogs may be incapable of experiencing the more complex social emotions, or their experiences may be qualitatively very different from ours. The reason the dog is human's best friend may be the apparently missing canine capacity for secondary emotions such as contempt or Schadenfreude (the joy in others' misfortune).

The secondary emotions seem to require some sense of the self (Leary 2003). Having self-awareness complicates the emotional experience in many ways - allowing imagined experiences with no basis in reality. Leary (2003) clarifies the effect of self on emotional experience through five points: "Specifically, having a self permits people to (1) evoke emotions in themselves by imaging self-relevant events, (2) react emotionally to abstract and 
symbolic images of themselves in their own minds, (3) consciously contemplate the cause of their emotions, (4) experience emotions by thinking about how they are perceived by other people, and (5) deliberately regulate their emotional experience" (p. 775). As he also points out, animals do not need a concept of self in order to have a basic emotion. Humans often attempt to suppress self-referential emotional thought in various ways (e.g., by drinking alcohol) since such thoughts can cause increasing distress. In children, self-awareness appears to arise roughly concurrently with the ability to take another's perspective (Lempers et al. 1977); early studies suggest similar co-occurrences in other species (Gallup \& Suarez 1986). To date, the level of dogs' self-awareness is not known - for example, they have not passed Gallup's (1986) mirror self-recognition test, but they do spend less time inspecting their own urine markings than those of others (Bekoff 2001).

The brain regions responsible for secondary emotions include a network comprising the medial orbitofrontal cortex, the temporal pole, and the superior temporal sulcus in humans (Moll et al. 2002, Burnett \& Blakemore 2009). In principle, homologues of these regions may also be present in the brains of dogs, in the temporal and frontal association areas. Homologues in cortices are difficult to verify because the brain functions of these cortical regions cannot be localized anatomically, thus functional brain imaging is needed. Nevertheless, the cortical association areas, associated with secondary emotions in humans, are larger in humans than in dogs $(20 \%$ of the cortex in dogs and $85 \%$ in humans; Evans \& de Lahunta 2013).

The brain areas responding to secondary emotions are also strongly connected to areas of the limbic system, and the connections alter the level of cognitive evaluation of the emotional states (Berridge 2003). The connections between the cortex and the limbic system are so different in magnitude between humans and other mammals that cortical lesions having minimal effects on other mammals may cause drastic changes in human function (Berridge 2003). For example, a cat without a cortex may still move and behave like a cat, whereas a human without a cortex, if alive, lies in a hospital bed completely unresponsive. Thus, it is possible that the re-representation of emotions that human encephalization produces with the interconnections to the limbic system may be the source of secondary emotions. In other words, as humans we have the potential to be angry, realize that we are angry, ponder the causes of our anger, notice that the anger momentarily affects our ability to work or cooperate, try to suppress our anger, think about how our anger appears to our companions and how it affects our relationships, and try to modify the source of the anger. If the cerebral-limbic interconnections are the source of this emotional re-representational ability in humans, the overall capacity of dogs for secondary emotions, with less encephalization than humans, may be dramatically different from ours.

\section{Do dogs display guilt — or merely appeasement?}

Guilt is an example of a secondary emotion often attributed to dogs, but according to current research, it fits the dog mind poorly. Horowitz (2009b) first recorded canine behavior and gestural cues in a situation where dogs could disobey the guardian's command and eat a forbidden treat. By manipulating the guardian's belief about what happened in the situation, she showed that dogs' gestures were not different whether or not they obeyed. Instead, the gestures commonly associated with dog "guilt" — for example, avoiding eye contact, wagging 
the tail low and quickly, holding one's ears or head down - were evident when the guardians scolded their dogs, regardless of the dog's actual behavior in the experiment. This strongly suggested that the dogs responded to the guardian's behavior with submissive gestures interpreted by dog guardians as "guilt," rather than displaying remorse for a misdeed with the "guilty" gestures (Horowitz 2009b). After a dog has learned the association between a certain unwanted behavior (e.g., stealing food) and the guardian's punishment later, they may display the submissive behavior in a similar situation even before the guardian's scolding (Horowitz 2009b). This does not require remorse or an "understanding" of violating a norm, but a simple learned association between two successive situations. When dogs display "guilt" behavior, guardians are likely to scold their dog less, which suggests that "guilt" behavior may function as learned appeasement (Hecht et al. 2012).

In a recent work, pet dogs' heart rates were measured during the "forbidden treat" experiment, and dogs who took the forbidden treat had a higher heart rate than dogs who did not (Torres-Pereira \& Broom 2014). This suggests a learned association between eating the treat and a possible consequent scolding. To ensure that the rise in heart rate was not merely a function of sympathetic nervous system activation in the active condition (eating a forbidden treat), a similar result should be obtained with dogs eating a treat that they were allowed. Alternatively, as both positive and negative stress can increase sympathetic nervous system activation, the treat-stealing dogs may just be more excited by the treat. Nevertheless, even representation of the causality of the action plus an anticipatory response to the consequence does not require a sense of guilt.

\section{Fairness or unequal treatment of conspecifics}

Another example of dog affective representations closer to the secondary emotions is inequity aversion (Figure 4). In studies of primate social cooperation, unequal treatment of individuals is related to negative responses (for review, de Waal \& Suchak 2010). In humans, the feeling of inequality is characterized by a negative response to the violation of fairness (for reviews, see Fehr \& Rockenbach 2004, Fehr \& Camerer 2007). A degree of inequity aversion was reported in capuchin monkeys (Cebus apella, Brosnan \& De Waal 2003) and chimpanzees (Pan troglodytes, Brosnan et al. 2005), and a few studies have investigated the phenomenon in dogs (Range et al. 2009, Horowitz 2012, Range et al. 2012, Brucks et al. 2016). In a situation where a conspecific partner was rewarded for a task and canine subjects were not, they refused to perform the task or hesitated longer (Range et al. 2009, Brucks et al. 2016). 


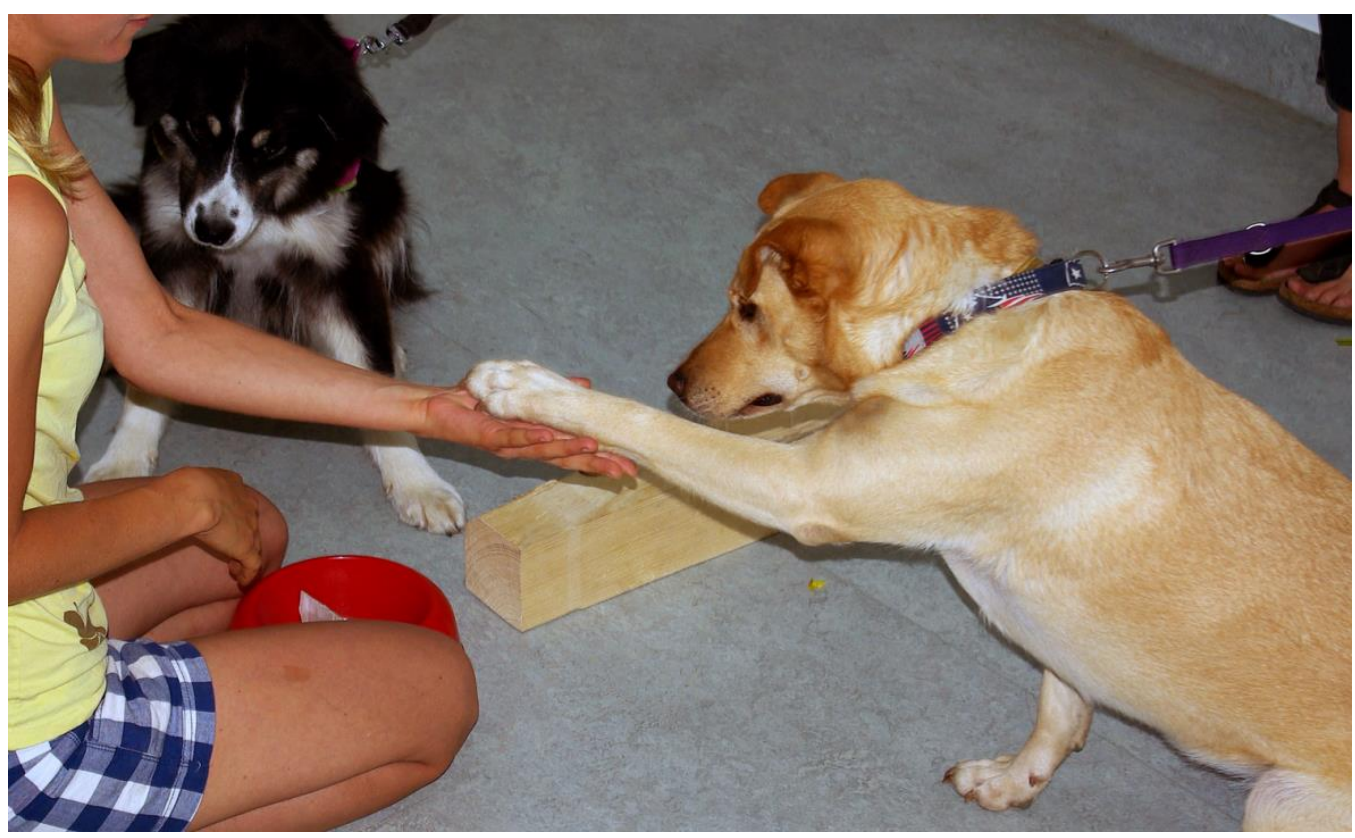

Figure 4. Testing dog inequity aversion; both dogs are asked to give the paw in turn. Figure from http://dx.doi.org/10.1371/journal.pone.0153799.g001 (Brucks et al. 2016), reprinted under the terms of the Creative Commons Attribution License.

The phenomenon does not qualify as a simple extinction of a learned behavior because the canine subjects refused to obey earlier after witnessing a partner receive a reward for obeying, compared to being alone (Range et al. 2009, Range et al. 2012, Brucks et al. 2016). They also tended to refuse earlier in the unequal situation than in the situation where neither dog received rewards (Range et al. 2009, Range et al. 2012). Dogs also shared their food and interacted less with partners after unequal situations, showing that the negative experience of unequal treatment, or not being rewarded for one's efforts, diminishes subsequent cooperation and tolerance of company (Brucks et al. 2016).

Humans and some other primates can resist unequal treatment (i.e., refuse to cooperate) either when they gain less than the partner or when they gain more (Brosnan et al. 2010, Blake \& McAuliffe 2011). In contrast, dogs do not resist the inequity when they are more rewarded than their companions (Horowitz 2012).

Taken together, dogs are sensitive to conspecific company in the inequity aversion test. They refuse earlier to perform the task in situations when they receive fewer rewards than their partner, compared to when they are alone, but unlike some primates, they do not resist gaining more than the partner. Although dogs behave differently toward the companion and experimenter after unequal and equal conditions (Brucks et al. 2016), this could also reflect the negative overall mood created by not being rewarded. The data to date suggest that dogs have the capacity for inequity aversion, but future work is needed with more conditions such as varying food quantities and the direction of the inequality, learning through a social model, expectation violation, negative situations affecting subsequent behavior, and individual factors such as personality or breed. 


\section{Resource competition as a precursor of jealousy?}

Another case of possible secondary emotions in dogs is jealousy. Dog guardians report behaviors related to jealousy as often as behaviors related to the basic emotion of anger (Morris et al. 2008). However, this also illustrates anthropomorphic misunderstandings: Couples may report that "On the rare occasion that we have a cuddle he'll start barking and whining." But hugging is not in dogs' natural behavior repertoire, so people cuddling can appear to dogs as a threat between pack members, to which they react by whining or trying to separate the "fighting pack members." In humans, jealousy usually concerns romantic relationships and extends to imaginary situations of a rival threatening a significant relationship (Leary 2003). A precursor of jealousy in dogs may exist in a situation of defending a previously gained resource such as a human companion.

In a recent behavioral study where dog guardians ignored their dogs and attended to realistic toy dogs or other objects, the dogs exhibited significantly more behaviors such as going between the guardian and the target of their attention, or pushing/touching the guardian or the target, when the target was a realistic toy dog rather than an object (Harris \& Prouvost 2014). Similarly, human infants showed more negative responses when a mother's attention was directed towards a life-like doll than an object like a book (Hart et al. 1998, Hart \& Carrington 2002).

Although the current data are consistent with the possibility of situation-based resource defense being a precursor of jealousy, the evidence for envy or jealousy in dogs is inconclusive and more rigorous research is required. Unfortunately, the behaviors associated with dog jealousy can also appear in dogs as replacement behaviors, when the dog is confused as to how to react.

\section{Divisions of empathy}

The neuroscientific study of human empathy exploded in the beginning of the 2000s (see Singer et al. 2004, Jackson et al. 2005, Gazzola et al. 2006, Saarela et al. 2007), revealing that the emotional aspect of empathy is processed in the limbic system, insula, and anterior cingulate cortex. Similar patterns may be also possible in the canine brain. Although simple forms of non-human empathy had been studied in previous decades (Church 1959, Rice \& Gainer 1962, Masserman et al. 1964, Watanabe \& Ono 1986), interest in animal and human empathy grew with the study of non-human primates (for reviews, Preston \& de Waal 2002, de Waal \& Ferrari 2010), and also extended to non-primates, including rats (Rattus norvegicus, Ben-Ami Bartal et al. 2011).

In humans, empathy has three components: emotional empathy, cognitive empathy, and the separation of the self from the other (see Decety \& Jackson 2004). Emotional empathy can be further divided into emotional contagion/self-distress and empathic concern: emotional contagion originates from automatically triggered responses to others' emotions, and empathic concern includes expressing a worry about others' wellbeing (Davis 1980). Emotional contagion is important for compassion, but at high levels it may lead to anxiety and passivity or aggression and antisociality rather than helping behavior (Roberts \& Strayer 1996). Cognitive empathy involves a theory-of-mind-like meta-representation of another's

emotional state. To highlight the difference between emotional and cognitive empathy, the 
latter can be fully preserved in humans diagnosed with psychopathic tendencies, whereas this population shows much less emotional contagion and empathic concern (Blair 2005), possibly due to altered limbic function (Birbaumer et al. 2005).

\section{From emotional contagion to prosocial behavior in dogs}

Although long recognized by some (see e.g., Bekoff 2007), the capability of dogs to empathize has been receiving more scientific attention recently. Anecdotal reports of dogs apparently consoling conspecifics or humans are abundant, but the topic has been thoroughly examined only in a few experiments.

Most research on dogs' empathy-related behavior toward conspecifics concerns behavior that resembles consolation, that is, reconciliation or post-conflict affiliation. In cooperative species, aggression toward conspecifics may be costly for the whole group. An important mechanism for managing the effects of aggression is post-conflict affiliative behavior between the former opponents (reconciliation), sometimes through mediation by a third party (de Waal \& van Roosmalen 1979). Both reconciliation behavior and third-party post-conflict affiliation are present in group-living dogs and wolves in heightened greeting; sitting or lying down together; and sniffing, playing, or licking the victim of aggression (Cools et al. 2007, Palagi \& Cordoni 2009, Cordoni \& Palagi 2015). Emotional contagion across dogs was recently studied by playing familiar and unfamiliar conspecific whines to dogs and examining their behavior during the playback and reunion with the familiar dogs (QuervelChaumette et al. 2016). When exposed to dog whines (recorded when the dog was left alone), the canine subjects were more alert and exhibited more stress-related behaviors compared with exposure to acoustically matched control sounds (Quervel-Chaumette et al. 2016). Additionally, exposure to familiar dog whines triggered more comfort-offering behaviors toward the partner dogs in reunion, resembling post-conflict affiliative behavior observed in natural groups (Cools et al. 2007, Palagi \& Cordoni 2009, Cordoni \& Palagi 2015). Postconflict affiliation highlights the possibility of emotional contagion or empathic concern in dogs, although its mechanisms are unknown.

Across-species affiliative interaction between a dog and their caretaker (e.g., guardian petting the dog) can cause hormonal and physiological synchronization, lowering cortisol levels and increasing oxytocin and dopamine levels in both species (Odendaal \& Meintjes 2003, Miller et al. 2009, Nagasawa et al. 2009, Handlin et al. 2011, Nagasawa et al. 2015). This across-species emotional synchronization suggests a possible physiological mechanism for the emotional contagion both in humans and dogs. In a similar example related to the stress response, cortisol levels in both humans and dogs increased significantly after listening to a crying human infant compared with a babbling infant or white noise (Yong \& Ruffman 2014).

Dogs may also act prosocially, pulling a rope that delivers a partner dog a reward even when the puller dogs themselves are not rewarded, but only if the recipient dog is familiar (Quervel-Chaumette et al. 2015). Similar helping behavior from dogs to humans was previously found (for review, Bräuer 2015). These results show the possibility of dogs' altruistic behavior. More studies on the extent of this kind of behavior. Overall, the studies show emotional contagion from humans across species to dogs, as well as from dogs to their conspecifics, although the underlying mechanisms of contagion are currently not clear. 


\section{Yawning contagiousness in dogs: Empathy or social relaxation?}

Contagious yawning is not used as a measure of empathy in human psychology, since well-validated questionnaires (e.g., Mehrabian \& Epstein 1972, Davis 1980, Lawrence et al. 2004, Dadds et al. 2008) can be combined with either behavioral studies (especially in children, see e.g., Eisenberg \& Miller 1987, Eisenberg \& Fabes 1990, Roberts \& Strayer 1996, Eisenberg et al. 1999) or brain imaging studies (for reviews, Decety \& Jackson 2004, Bernhardt \& Singer 2012) to show a correspondence between self-reported reactivity and behavioral or physiological changes. Early studies reported diminished contagiousness of yawning in children with Autism Spectrum Disorders (ASD) (Senju et al. 2007, Giganti \& Esposito Ziello 2009, Helt et al. 2010), which prompted speculation regarding the possible relation of contagious yawning to empathy. Newer studies have reported the capacity for contagious yawning in children with ASD (Senju et al. 2009, Usui et al. 2013) and the independence of yawning contagiousness from empathy (Bartholomew \& Cirulli 2014). However, since the inaugural study showing yawn contagion across species from humans to dogs (Joly-Mascheroni et al. 2008), a range of studies has explored the possible connection of contagious yawning and empathy in canines (O'Hara \& Reeve 2011, Silva et al. 2012, Madsen \& Persson 2013, Romero et al. 2013, Silva et al. 2013, Buttner \& Strasser 2014, Romero et al. 2014).

Yawning is a somewhat problematic measure in dogs because the canine yawn serves as a tension-releasing stress response (see e.g., Beerda et al. 1998). Nevertheless, many studies found a higher frequency of canine yawning after observing or hearing a human yawn (Joly-Mascheroni et al. 2008, Silva et al. 2012, Madsen \& Persson 2013, Romero et al. 2013). Some studies also reported stronger yawn contagiousness in dogs after perceiving a familiar rather than non-familiar person yawning (Silva et al. 2012, Romero et al. 2013). This effect of social connectedness was also demonstrated within wolves (Romero et al. 2014).

In humans, the tendency to yawn after witnessing another person's yawn is negatively correlated with amygdala activation (Schürmann et al. 2005). Thus, higher amygdala activation, which may occur naturally in unknown company as vigilance for a threat (e.g., Whalen 1998, Hart et al. 2000), acts against yawning contagion. If a similar connection existed in canids, familiarity would increase contagious yawning merely as a function of the individual's level of social relaxedness. The yawn contagiousness in dogs, however, adds to the possibility of interspecific emotional synchronization and contagion in relaxation (Odendaal \& Meintjes 2003, Miller et al. 2009, Nagasawa et al. 2009, Handlin et al. 2011, Nagasawa et al. 2015).

Altogether, the studies of empathy show that at least emotional contagion is possible in dogs. Studies on canine post-conflict affiliative behavior and prosociality also suggest some empathic concern. A recent study on canine prosocial tendencies (Quervel-Chaumette et al. 2015) also reported situation-dependent perspective-taking. The extent of empathic capacity in dogs is unknown, however (for discussion, see also Silva \& de Sousa 2011). There are probably limits to the cognitive component of empathy in dogs: They lack metarepresentational and self-representational skills because their brains have less encephalization and connectivity than humans. However, coupled with the rudimentary theory of mind hypothesized by Horowitz (2011), empathic responding may not be an all-ornone function but an ability that occurs to various degrees across social species. 


\section{Long-term moods: A "cognitive judgment bias" test}

The effects of rearing environment on emotional response in animals were noted in the 1950s by psychologists such as Hebb (1955). Raising dogs in a restricted environment affected their subsequent emotional responses (Melzack 1954). Fifty years later, the work was extended into the field of animal welfare, and the effect of the environment on the positive or negative affective states in animals was studied using an emotional judgment bias test (Harding et al. 2004). The effect is called "cognitive judgment bias" or "cognitive bias" in the animal sciences (Mendl et al. 2010a, Rygula et al. 2015), although human psychology has a multitude of different cognitive biases (see e.g., Tversky \& Kahneman 1974, Haselton et al. 2005). This expectation-related "cognitive bias" is also based on studies of humans in which the phenomenon is widely known as affective congruence (e.g., Bower 1991, Fazio 2010): anxious or depressed people tend to interpret ambiguous stimuli negatively (Eysenck et al. 1991, Wright \& Bower 1992, MacLeod \& Byrne 1996, Gotlib \& Krasnoperova 1998). Nonhuman animals may also be biased in their expectations after negative or positive experiences (Mendl et al. 2010b).

The basic test is simple: animals are first trained that one stimulus (e.g., a black card) signals a positive event (reward, e.g., food), and another (a white card) signals a negative event (a punishment). After such training, they are presented with ambiguous, intermediate signals (e.g., a grey card), and their reactions (e.g., time of approaching the stimulus) to the ambiguous signals are recorded. In dogs, a food bowl is placed in one corner of a room and an empty bowl in another corner (Mendl et al. 2010a). When dogs learn to discriminate the two locations, a bowl is placed between them. In the test trials, approach time to the ambiguous locations is measured: a quick approach indicates anticipation of food, an "optimistic" judgment, and a slow approach indicates a "pessimistic" judgment (Mendl et al. 2010a).

Dogs with higher separation-related anxiety approach the ambiguous bowl locations more slowly, showing a negative cognitive bias (Mendl et al. 2010a). Anxiolytic medication with the human anti-depressant fluoxetine combined with behavioral modification diminishes the bias (Karagiannis et al. 2015). However, leaving dogs alone for a brief time does not generate negative expectations (Müller et al. 2012), suggesting that it is a prolonged emotional state that induces negative bias in dogs (Mendl et al. 2010a). Likewise, briefly searching for treats prior to testing was not enough to induce positive bias in dogs (Burman et al. 2011), whereas administering oxytocin prior to testing caused positive bias (Kis et al. 2015).

To date, it seems that the cognitive bias test measures long-term tendencies, expectations, and moods rather than sudden emotions. Inducing the positive or negative expectations experimentally has proven tricky, leaving room for further investigation. 


\section{Emotional and social data across species: Emotional evolution?}

Although direct data on dog emotions are currently quite rare, there are more studies on dog skills in interspecific cooperative-communicative social tasks. In these tasks, parallel experiments in dogs and other canids, carnivores, and non-human primates have been extremely informative. Regarding evolutionary changes in emotion leading to changes in social cognition, Hare (2007) has suggested that 'dogs' specialized social-problem-solving skills may have first appeared after systems mediating fear and aggression were altered" (p. 62). In the long-term studies on experimental domestication of foxes, selective breeding for low levels of fear and aggression toward humans were associated with changes in foxes' limbic systems (Trut 2001), and as a side-effect, their social cognitive abilities (Hare et al. 2005). This Emotional Reactivity Hypothesis (Hare \& Tomasello 2005) was recently tested with dogs and wolves by Range, Ritter, and Viranyi (2015). In a cooperative situation, wolves were not more aggressive towards conspecifics than dogs. Thus, the modified Canine Cooperation Hypothesis is that dog-human cooperation might have originated from wolfwolf tolerance and cooperation (Range \& Viranyi 2014, Range et al. 2015).

The suggestion that there is interplay between emotional and social skills in dogs is intriguing, and merits a closer examination of the brain circuitries involved.

\section{Methodological advances and future directions}

Human and nonhuman emotions have a long history of being studied using different methods (Berridge 2003). Therefore, using comparable methods in humans and dogs should provide valuable new insights (for example, Racca et al. 2012, Andics et al. 2014, Törnqvist et al. 2015, Yong \& Ruffman 2016). Methodological advances include non-invasive brain imaging usually used with humans, such as functional magnetic resonance imaging (Berns et al. 2012, Andics et al. 2014, Jia et al. 2014, Berns et al. 2015, Dilks et al. 2015, Cuaya et al. 2016) and surface-electroencephalography (Howell et al. 2012, Kujala et al. 2013, Törnqvist et al. 2013, Kis et al. 2014). These can now be used with dogs together with positive operantconditional training. Thermographic imaging also appears promising for detecting emotionally-stimulated changes in body surface temperature (Travain et al. 2015, Riemer et al. 2016, Travain et al. 2016). All these new techniques require careful experimentation to avoid the possible confounds reported for human research (importantly, see Bennett et al. 2009, Kriegeskorte et al. 2009, Poldrack \& Mumford 2009, Vul et al. 2009).

Numerous topics, such as theory of mind in dogs, and possible emotional lateralization or gender effects, deserved more discussion. Many personal and environmental factors underlie individual differences in human emotional processes (e.g., Tomarken et al. 1992, Canli et al. 2002, de Rosnay \& Harris 2002, Gross \& John 2003), and similar variation also occurs in dogs (see e.g., Gosling et al. 2003, Fratkin et al. 2013, Cook et al. 2014). Dominance relations may affect canine emotions through cerebral neurochemical concentrations (for review, Chichinadze et al. 2014). Skull shape in dogs can also affect brain formation and hence cognition and emotion (McGreevy et al. 2004, Helton 2009, Roberts et al. 2010, McGreevy et al. 2013). There is also no reason dogs could not have unique emotional states that humans do not have, for example, states related to their olfactory world and the function of the piriform cortex. These topics will certainly receive more attention in the future. We need 
more studies of the emotional world of dogs along with sensible caution in interpreting and generalizing the results.

\section{Acknowledgments}

This work was enabled by the Brain Research collaboration between the Aalto University and University of Helsinki (BRAHE initiative); Emil Aaltonen Foundation Personal Grant (\#160121); and Tekes grant \#7244/31/2016. In addition to the editors and reviewers, I wish to thank my colleagues from various fields in the human and animal sciences for their comments on an earlier draft of the article: Otto Lappi, Sanni Somppi, Helena Telkänranta, Riitta Hari, Jari Hietanen, Jukka Leppänen, Outi Vainio, and Katriina Tiira.

Call for Commentary: Animal Sentience publishes Open Peer Commentary on all accepted target articles. Target articles are peer-reviewed. Commentaries are editorially reviewed. There are submitted commentaries as well as invited commentaries. Commentaries appear as soon as they have been reviewed, revised and accepted. Target article authors may respond to their commentaries individually or in a joint response to multiple commentaries.

Instructions: http://animalstudiesrepository.org/animsent/guidelines.html

\section{References}

Adolphs, R. (2002). Recognizing emotion from facial expressions: psychological and neurological mechanisms. Behavioral and Cognitive Neuroscience Reviews, 1, 21-62. doi:10.1177/1534582302001001003

Albuquerque, N., Guo, K., Wilkinson, A., Savalli, C., Otta, E. \& Mills, D. (2016). Dogs recognize dog and human emotions. Biology Letters, 12, 20150883. doi:10.1098/rsbl.2015.0883

Anderson, D. J. \& Adolphs, R. (2014). A framework for studying emotions across species. Cell, 157, 187-200. doi:10.1016/j.cell.2014.03.003

Andics, A., Gácsi, M., Faragó, T., Kis, A. \& Miklósi, A. (2014). Voice-sensitive regions in the dog and human brain are revealed by comparative fMRI. Current Biology, 24, 574-578. doi:10.1016/j.cub.2014.01.058

Ascione, F. R. (1992). Enhancing childrens attitudes about the humane treatment of animals: generalization to human-directed empathy. Anthrozoös, 5, 176-191. doi:10.2752/089279392787011421

Barber, A. L., Randi, D., Müller, C. A. \& Huber, L. (2016). The processing of human emotional faces by pet and lab dogs: evidence for lateralization and experience effects. Plos ONE, 11, e0152393. doi:10.1371/journal.pone.0152393

Bartholomew, A. J. \& Cirulli, E. T. (2014). Individual variation in contagious yawning susceptibility is highly stable and largely unexplained by empathy or other known factors. Plos ONE, 9, e91773. doi:10.1371/journal.pone.0091773

Beaver, B. V. (1983). Clinical classification of canine aggression. Applied Animal Ethology, 10, 35-43. doi:10.1016/0304-3762(83)90110-4 
Beerda, B., Schilder, M. B. H., van Hooff, J. A. R. A. M., de Vries, H. W. \& Mol, J. A. (1998). Behavioural, saliva cortisol and heart rate responses to different types of stimuli in dogs. Applied Animal Behaviour Science, 58, 365-381. doi:10.1016/S0168-1591(97)00145-7

Bekoff, M. (1974a). Social play and play-soliciting by infant canids. American Zoologist, 14, 323-340. URL: http://www.jstor.org/stable/3881994

Bekoff, M. (1974b). Social play in coyotes, wolves, and dogs. Bioscience, 24, 225-230. doi:10.2307/1296803

Bekoff, M. (1995). Play signals as punctuation: the structure of social play in canids. Behaviour, 132, 419-429. doi:10.1163/156853995x00649

Bekoff, M. (2001). Observations of scent-marking and discriminating self from others by a domestic dog (Canis familiaris): tales of displaced yellow snow. Behavioural Processes, 55, 75-79. doi:10.1016/S0376-6357(01)00142-5

Bekoff, M. (2007). The emotional lives of animals. Novato, CA: New World Library.

Ben-Ami Bartal, I., Decety, J. \& Mason, P. (2011). Empathy and pro-social behavior in rats. Science, 334, 1427-1430. doi:10.1126/science.1210789

Bennett, C. M., Miller, M. \& Wolford, G. (2009). Neural correlates of inter-species perspective taking in the post-mortem Atlantic Salmon: an argument for multiple comparisons correction. Neuroimage, 47, S125. doi:10.1016/S1053-8119(09)71202-9

Bernhardt, B. C. \& Singer, T. (2012). The neural basis of empathy. Annual review of Neuroscience, 35, 1-23. doi:10.1146/annurev-neuro-062111-150536

Berns, G. S., Brooks, A. M. \& Spivak, M. (2012). Functional MRI in awake unrestrained dogs. Plos ONE, 7, e38027. doi:10.1371/journal.pone.0038027

Berns, G. S., Brooks, A. M. \& Spivak, M. (2015). Scent of the familiar: an fMRI study of canine brain responses to familiar and unfamiliar human and dog odors. Behavioural Processes, 110, 37-46. doi:10.1016/j.beproc.2014.02.011

Berridge, K. C. (2003). Comparing the emotional brains of humans and other animals. In R. J. Davidson, K. R. Scherer \& H. H. Goldsmith (Eds.), Handbook of affective sciences (pp. 2551). New York: Oxford University Press

Birbaumer, N., Veit, R., Lotze, M., Erb, M., Hermann, C., Grodd, W. \& Flor, H. (2005). Deficient fear conditioning in psychopathy: a functional magnetic resonance imaging study. Archives of General Psychiatry, 62, 799-805. doi:10.1001/archpsyc.62.7.799

Blair, R. J. (2005). Responding to the emotions of others: dissociating forms of empathy through the study of typical and psychiatric populations. Consciousness and Cognition, 14, 698-718. doi:10.1016/j.concog.2005.06.004

Blake, P. R. \& McAuliffe, K. (2011). "I had so much it didn't seem fair": eight-year-olds reject two forms of inequity. Cognition, 120, 215-224. doi:10.1016/j.cognition.2011.04.006

Bloom, T. \& Friedman, H. (2013). Classifying dogs' (Canis familiaris) facial expressions from photographs. Behavioural Processes, 96, 1-10. doi:10.1016/j.beproc.2013.02.010

Blythe, P. W., Todd, P. M. \& Miller, G. F. (1999). How motion reveals intention: categorizing social interactions. In G. Gigerenzer, P. M. Todd \& T. A. R. Group (Eds.), Simple heuristics that make us smart (pp. 257-285). New York: Oxford University Press

Bolwig, N. (1964). Facial expression in primates with remarks on a parallel development in certain carnivores (A preliminary report on work in progress). Behaviour, 22, 167-192. URL: http://www.jstor.org/stable/4533071 
Bower, G. H. (1991). Mood congruity of social judgments. In J. P. Forgas (Ed.), Emotion and social judgments (pp. 31-53). Oxford: Pergamon Press.

Bräuer, J. (2015). I do not understand but I care: the prosocial dog. Interaction Studies, 16, 341-360. doi: 10.1075/is.16.3.01bra

Brosnan, S. F. \& De Waal, F. B. (2003). Monkeys reject unequal pay. Nature, 425, 297-299. doi:10.1038/nature01963

Brosnan, S. F., Schiff, H. C. \& de Waal, F. B. (2005). Tolerance for inequity may increase with social closeness in chimpanzees. Proceedings of the Royal Society B: Biological Sciences, 272, 253-258. doi:10.1098/rspb.2004.2947

Brosnan, S. F., Talbot, C., Ahlgren, M., Lambeth, S. P. \& Schapiro, S. J. (2010). Mechanisms underlying responses to inequitable outcomes in chimpanzees, Pan troglodytes. Animal Behaviour, 79, 1229-1237. doi:10.1016/j.anbehav.2010.02.019

Brucks, D., Essler, J. L., Marshall-Pescini, S. \& Range, F. (2016). Inequity aversion negatively affects tolerance and contact-seeking Bbehaviours towards partner and experimenter. Plos ONE, 11, e0153799. doi:10.1371/journal.pone.0153799

Buckland, E. L., Volk, H. A., Burn, C. C. \& Abeyesinghe, S. M. (2014). Guardian perceptions of companion dog expressions of positive emotional states and the contexts in which they occur. Animal Welfare, 23, 287-296. doi:10.7120/09627286.23.3.287

Burman, O., McGowan, R., Mendl, M., Norling, Y., Paul, E., Rehn, T. \& Keeling, L. (2011). Using judgement bias to measure positive affective state in dogs. Applied Animal Behaviour Science, 132, 160-168. doi:10.1016/j.applanim.2011.04.001

Burnett, S. \& Blakemore, S. J. (2009). Functional connectivity during a social emotion task in adolescents and in adults. European Journal of Neuroscience, 29, 1294-1301. doi:10.1111/j.1460-9568.2009.06674.x

Bush, G., Luu, P. \& Posner, M. I. (2000). Cognitive and emotional influences in anterior cingulate cortex. Trends in Cognitive Sciences, 4, 215-222. doi:10.1016/S13646613(00)01483-2

Buttelmann, D. \& Tomasello, M. (2013). Can domestic dogs (Canis familiaris) use referential emotional expressions to locate hidden food? Animal Cognition, 16, 137-145. doi:10.1007/s10071-012-0560-4

Buttner, A. P. \& Strasser, R. (2014). Contagious yawning, social cognition, and arousal: an investigation of the processes underlying shelter dogs' responses to human yawns. Animal Cognition, 17, 95-104. doi:10.1007/s10071-013-0641-z

Caeiro, C. C., Waller, B. M., Burrows, A. M., Zimmermann, E. \& Davila-Ross, M. (2013). OrangFACS: a muscle-based coding system for orangutan facial movements. International Journal of Primatology, 34, 115-129. doi:10.1007/s10764-012-9652-x

Calder, A. J. \& Young, A. W. (2005). Understanding the recognition of facial identity and facial expression. Nature Reviews Neuroscience, 6, 641-651. doi:10.1038/nrn1724

Call, J., Bräuer, J., Kaminski, J. \& Tomasello, M. (2003). Domestic dogs (Canis familiaris) are sensitive to the attentional state of humans. Journal of Comparative Psychology, 117, 257-263. doi:10.1037/0735-7036.117.3.257

Cameron, D. B. (1997). Canine dominance-associated aggression: concepts, incidence, and treatment in a private behavior practice. Applied Animal Behaviour Science, 52, 265-274. doi:10.1016/S0168-1591(96)01127-6 
Canli, T., Sivers, H., Whitfield, S. L., Gotlib, I. H. \& Gabrieli, J. D. (2002). Amygdala response to happy faces as a function of extraversion. Science, 296, 2191.

doi:10.1126/science.1068749

Chaminade, T., Hodgins, J. \& Kawato, M. (2007). Anthropomorphism influences perception of computer-animated characters' actions. Social Cognitive \& Affective Neuroscience, 2, 206-216. doi:10.1093/scan/nsm017

Chichinadze, K., Chichinadze, N., Gachechiladze, L., Lazarashvili, A. \& Nikolaishvili, M. (2014). Physical predictors, behavioural/emotional attributes and neurochemical determinants of dominant behaviour. Biological Reviews of the Cambridge Philosophical Society, 89, 1005-1020. doi:10.1111/brv.12091

Church, R. M. (1959). Emotional reactions of rats to the pain of others. Journal of Comparative and Physiological Psychology, 52, 132-134. doi:10.1037/h0043531

Cook, P. F., Spivak, M. \& Berns, G. S. (2014). One pair of hands is not like another: caudate BOLD response in dogs depends on signal source and canine temperament. PeerJ, 2, e596. doi:10.7717/peerj.596

Cools, A. K. A., Van Hout, A. J. M. \& Nelissen, M. H. J. (2007). Canine reconciliation and thirdparty-initiated postconflict affiliation: Do peacemaking social mechanisms in dogs rival those of higher primates? Ethology, 114, 53-63. doi:10.1111/j.1439-0310.2007.01443.x

Cordoni, G. \& Palagi, E. (2015). Being a victim or an aggressor: different functions of triadic post-conflict interactions in wolves (Canis lupus lupus). Aggressive Behavior, 41, 526536. doi:10.1002/ab.21590

Cuaya, L. V., Hernandez-Perez, R. \& Concha, L. (2016). Our faces in the dog's brain: Functional imaging reveals temporal cortex activation during perception of human faces. Plos ONE, 11, e0149431. doi:10.1371/journal.pone.0149431

Cullen, H., Kanai, R., Bahrami, B. \& Rees, G. (2014). Individual differences in anthropomorphic attributions and human brain structure. Social Cognitive and Affective Neuroscience, 9, 1276-1280. doi:10.1093/scan/nst109

Dadds, M. R., Hunter, K., Hawes, D. J., Frost, A. D., Vassallo, S., Bunn, P., Merz, S. \& Masry, Y. E. (2008). A measure of cognitive and affective empathy in children using parent ratings. Child Psychiatry \& Human Development, 39, 111-122. doi:10.1007/s10578-007-0075-4

Damasio, A. R., Grabowski, T. J., Bechara, A., Damasio, H., Ponto, L. L., Parvizi, J. \& Hichwa, R. D. (2000). Subcortical and cortical brain activity during the feeling of self-generated emotions. Nature Neuroscience, 3, 1049-1056. doi:10.1038/79871

Darwin, C. (1872). The expression of the emotions in man and animals. London: John Murray

Datta, R., Lee, J., Duda, J., Avants, B. B., Vite, C. H., Tseng, B., Gee, J. C., Aguirre, G. D. \& Aguirre, G. K. (2012). A digital atlas of the dog brain. Plos ONE, 7, e52140. doi:10.1371/journal.pone.0052140

Davis, M. H. (1980). A multidimensional approach to individual differences in empathy. JSAS Catalog of Selected Documents in Psychology, 10, 85.

de Lahunta, A. \& Glass, E. (2009). Veterinary neuroanatomy and clinical neurology. St. Louis, MO: Saunders, Elsevier Inc.

de Rosnay, M. \& Harris, P. L. (2002). Individual differences in children's understanding of emotion: the roles of attachment and language. Attachment \& Human Development, 4, 39-54. doi:10.1080/14616730210123139 
de Waal, F. B. \& Ferrari, P. F. (2010). Towards a bottom-up perspective on animal and human cognition. Trends in Cognitive Sciences, 14, 201-207.

doi:10.1016/j.tics.2010.03.003

de Waal, F. B. \& Suchak, M. (2010). Prosocial primates: selfish and unselfish motivations. Philosophical Transactions of the Royal Society B: Biological Sciences, 365, 2711-2722. doi:10.1098/rstb.2010.0119

de Waal, F. B. \& van Roosmalen, A. (1979). Reconciliation and consolation among chimpanzees. Behavioral Ecology and Sociobiology, 5, 55-66. URL: http://www.jstor.org/stable/4599217

Decety, J. \& Jackson, P. L. (2004). The functional architecture of human empathy. Behavioral and Cognitive Neuroscience Reviews, 3, 71-100. doi:10.1177/1534582304267187

Dilks, D. D., Cook, P., Weiller, S. K., Berns, H. P., Spivak, M. \& Berns, G. S. (2015). Awake fMRI reveals a specialized region in dog temporal cortex for face processing. PeerJ, 3, e1115. doi:10.7717/peerj.1115

Dreschel, N. A. \& Granger, D. A. (2005). Physiological and behavioral reactivity to stress in thunderstorm-phobic dogs and their caregivers. Applied Animal Behaviour Science, 95, 153-168. doi:10.1016/j.applanim.2005.04.009

Duffy, D. L., Hsu, Y. Y. \& Serpell, J. A. (2008). Breed differences in canine aggression. Applied Animal Behaviour Science, 114, 441-460. doi:10.1016/j.applanim.2008.04.006

Eisenberg, N. \& Fabes, R. A. (1990). Empathy: conceptualization, measurement, and relation to prosocial behavior. Motivation and Emotion, 14, 131-149. doi:10.1007/BF00991640

Eisenberg, N., Guthrie, I. K., Murphy, B. C., Shepard, S. A., Cumberland, A. \& Carlo, G. (1999). Consistency and development of prosocial dispositions: a longitudinal study. Child Development, 70, 1360-1372. doi:10.1111/1467-8624.00100

Eisenberg, N. \& Miller, P. A. (1987). The relation of empathy to prosocial and related behaviors. Psychological Bulletin, 101, 91-119. doi:10.1037/0033-2909.101.1.91

Ekman, P. (1992). Are there basic emotions? Psychological Review, 99, 550-553. doi:10.1037/0033-295X.99.3.550

Ekman, P. \& Friesen, W. V. (1971). Constants across cultures in the face and emotion. Journal of Personality and Social Psychology, 17, 124-129. doi:10.1037/h0030377

Ekman, P. \& Friesen, W. V. (1978). Facial action coding system. CA: Consulting Psychology Press.

Ekman, P., Friesen, W. V., Osullivan, M., Chan, A., Diacoyannitarlatzis, I., Heider, K., Krause, R., Lecompte, W. A., Pitcairn, T., Riccibitti, P. E., Scherer, K., Tomita, M. \& Tzavaras, A. (1987). Universals and cultural-differences in the judgments of facial expressions of emotion. Journal of Personality and Social Psychology, 53, 712-717. doi:10.1037/00223514.53.4.712

Elfenbein, H. A. \& Ambady, N. (2002). On the universality and cultural specificity of emotion recognition: a meta-analysis. Psychological Bulletin, 128, 203-235. doi:10.1037//00332909.128.2.203

Epley, N., Waytz, A. \& Cacioppo, J. T. (2007). On seeing human: a three-factor theory of anthropomorphism. Psychological Review, 114, 864-886. doi:10.1037/0033295X.114.4.864 
Etkin, A., Egner, T. \& Kalisch, R. (2011). Emotional processing in anterior cingulate and medial prefrontal cortex. Trends in Cognitive Sciences, 15, 85-93. doi:10.1016/j.tics.2010.11.004

Evans, H. E. \& de Lahunta, A. (2013). Miller's anatomy of the dog. St. Louis, MO: Saunders, Elsevier Inc.

Eysenck, M. W., Mogg, K., May, J., Richards, A. \& Mathews, A. (1991). Bias in interpretation of ambiguous sentences related to threat in anxiety. Journal of Abnormal Psychology, 100, 144-150. doi:10.1037/0021-843X.100.2.144

Faragó, T., Andics, A., Devecseri, V., Kis, A., Gácsi, M. \& Miklósi, A. (2014). Humans rely on the same rules to assess emotional valence and intensity in conspecific and dog vocalizations. Biology Letters, 10, 20130926. doi:10.1098/rsbl.2013.0926

Fazio, R. H. (2010). On the automatic activation of associated evaluations: an overview. Cognition and Emotion, 15, 115-141. doi:10.1080/02699930125908

Fehr, E. \& Camerer, C. F. (2007). Social neuroeconomics: the neural circuitry of social preferences. Trends in Cognitive Sciences, 11, 419-427. doi:10.1016/j.tics.2007.09.002

Fehr, E. \& Rockenbach, B. (2004). Human altruism: economic, neural, and evolutionary perspectives. Current Opinion in Neurobiology, 14, 784-790. doi:10.1016/j.conb.2004.10.007

Fox, M. W. (1970). A comparative study of development of facial expressions in canids: wolf, coyote and foxes. Behaviour, 36, 49-73. doi:10.1163/156853970x00042

Franklin, R. G., Jr., Nelson, A. J., Baker, M., Beeney, J. E., Vescio, T. K., Lenz-Watson, A. \& Adams, R. B., Jr. (2013). Neural responses to perceiving suffering in humans and animals. Social Neuroscience, 8, 217-227. doi:10.1080/17470919.2013.763852

Fratkin, J. L., Sinn, D. L., Patall, E. A. \& Gosling, S. D. (2013). Personality consistency in dogs: a meta-analysis. Plos ONE, 8, e54907. doi:10.1371/journal.pone.0054907

Gallup, G. G., Jr. \& Suarez, S. D. (1986). Self-awareness and the emergence of mind in humans and other primates. In J. Suls \& A. Greenwald (Eds.), Psychological perspectives on the self (Vol. 3) (pp. 3-26). Hillsdale, NJ: Erlbaum.

Galvan, M. \& Vonk, J. (2016). Man's other best friend: domestic cats (F. silvestris catus) and their discrimination of human emotion cues. Animal Cognition, 19, 193-205. doi:10.1007/s10071-015-0927-4

Gazzola, V., Aziz-Zadeh, L. \& Keysers, C. (2006). Empathy and the somatotopic auditory mirror system in humans. Current Biology, 16, 1824-1829. doi:10.1016/j.cub.2006.07.072

Gazzola, V., Rizzolatti, G., Wicker, B. \& Keysers, C. (2007). The anthropomorphic brain: the mirror neuron system responds to human and robotic actions. Neuroimage, 35, 16741684. doi:10.1016/j.neuroimage.2007.02.003

Giganti, F. \& Esposito Ziello, M. (2009). Contagious and spontaneous yawning in autistic and typically developing children. Current Psychology Letters, 25, 1-11.

Goddard, M. E. \& Beilharz, R. G. (1986). Early prediction of adult behavior in potential guide dogs. Applied Animal Behaviour Science, 15, 247-260. doi:10.1016/01681591(86)90095-X

Gosling, S. D., Kwan, V. S. \& John, O. P. (2003). A dog's got personality: a cross-species comparative approach to personality judgments in dogs and humans. Journal of Personality and Social Psychology, 85, 1161-1169. doi:10.1037/0022-3514.85.6.1161 
Gotlib, I. H. \& Krasnoperova, E. (1998). Biased information processing as a vulnerability factor for depression. Behavior Therapy, 29, 603-617. doi:10.1016/S00057894(98)80020-8

Gross, J. J. \& John, O. P. (2003). Individual differences in two emotion regulation processes: implications for affect, relationships, and well-being. Journal of Personality and Social Psychology, 85, 348-362. doi:10.1037/0022-3514.85.2.348

Handlin, L., Hydbring-Sandberg, E., Nilsson, A., Ejdeback, M., Jansson, A. \& Uvnas-Moberg, K. (2011). Short-term interaction between dogs and their guardians: effects on oxytocin, cortisol, insulin and heart rate: an exploratory study. Anthrozoös, 24, 301-315. doi:10.2752/175303711x13045914865385

Harding, E. J., Paul, E. S. \& Mendl, M. (2004). Animal behaviour: cognitive bias and affective state. Nature, 427, 312. doi:10.1038/427312a

Hare, B. (2007). From nonhuman to human mind: what changed and why? Current Directions in Psychological Science, 16, 60-64. doi:10.1111/j.1467-8721.2007.00476.x

Hare, B. \& Tomasello, M. (2005). The emotional reactivity hypothesis and cognitive evolution: Reply to Miklósi and Topal. Trends in Cognitive Sciences, 9, 464-465. doi:10.1016/j.tics.2005.08.010

Hare, B., Call, J. \& Tomasello, M. (1998). Communication of food location between human and dog (Canis familiaris). Evolution of Communication, 2, 137-159. doi:10.1075/eoc.2.1.06har

Hare, B., Plyusnina, I., Ignacio, N., Schepina, O., Stepika, A., Wrangham, R. \& Trut, L. (2005). Social cognitive evolution in captive foxes is a correlated by-product of experimental domestication. Current Biology, 15, 226-230. doi:10.1016/j.cub.2005.01.040

Hari, R. \& Kujala, M. V. (2009). Brain basis of human social interaction: from concepts to brain imaging. Physiological Reviews, 89, 453-479. doi:10.1152/physrev.00041.2007

Harris, C. R. \& Prouvost, C. (2014). Jealousy in dogs. Plos ONE, 9, e94597. doi:10.1371/journal.pone.0094597

Harris, L. T. \& Fiske, S. T. (2006). Dehumanizing the lowest of the low: neuroimaging responses to extreme out-groups. Psychological Science, 17, 847-853. doi:10.1111/j.1467-9280.2006.01793.x

Harrison, M. A. \& Hall, A. E. (2010). Anthropomorphism, empathy, and perceived communicative ability vary with phylogenetic relatedness to humans. Journal of Social Evolutionary Cultural Psychology, 4, 34-48. doi:10.1037/h0099303

Hart, A. J., Whalen, P. J., Shin, L. M., McInerney, S. C., Fischer, H. \& Rauch, S. L. (2000). Differential response in the human amygdala to racial outgroup vs. ingroup face stimuli. Neuroreport, 11, 2351-2355.

Hart, S. \& Carrington, H. A. (2002). Jealousy in six-month-old infants. Infancy, 3, 395-402. doi:10.1207/S15327078IN0303_6

Hart, S., Field, T., Del Valle, C. \& Letourneau, M. (1998). Infants protest their mothers' attending to an infant-size doll. Social Development, 7, 54-61. doi:10.1111/14679507.00050

Haselton, M. G., Nettle, D. \& Andrews, P. W. (2005). The evolution of cognitive bias. In D. M. Buss (Ed.), The handbook of evolutionary psychology (pp. 724-746). Hoboken, NJ: John Wiley \& Sons Inc. 
Haslam, N. (2006). Dehumanization: an integrative review. Personality and Social Psychology Review, 10, 252-264. doi:10.1207/s15327957pspr1003_4

Haug, L. I. (2008). Canine aggression toward unfamiliar people and dogs. Veterinary Clinics of North America-Small Animal Practice, 38, 1023-1041. doi:10.1016/j.cvsm.2008.04.005

Haxby, J. V., Hoffman, E. A. \& Gobbini, M. I. (2000). The distributed human neural system for face perception. Trends in Cognitive Sciences, 4, 223-233. doi:10.1016/S13646613(00)01482-0

Hebb, D. 0. (1955). The mammal and his environment. American Journal of Psychiatry, 111, 826-831. doi:10.1176/ajp.111.11.826

Hecht, J., Miklósi, A. \& Gácsi, M. (2012). Behavioral assessment and guardian perceptions of behaviors associated with guilt in dogs. Applied Animal Behaviour Science, 139, 134-142. doi:10.1016/j.applanim.2012.02.015

Helt, M. S., Eigsti, I. M., Snyder, P. J. \& Fein, D. A. (2010). Contagious yawning in autistic and typical development. Child Development, 81, 1620-1631. doi:10.1111/j.14678624.2010.01495.x

Helton, W. S. (2009). Cephalic index and perceived dog trainability. Behavioural Processes, 82, 355-358. doi:10.1016/j.beproc.2009.08.004

Horowitz, A. (2009a). Attention to attention in domestic dog (Canis familiaris) dyadic play. Animal Cognition, 12, 107-118. doi:10.1007/s10071-008-0175-y

Horowitz, A. (2009b). Disambiguating the "guilty look": salient prompts to a familiar dog behaviour. Behavoural Processes, 81, 447-452. doi:10.1016/j.beproc.2009.03.014

Horowitz, A. (2011). Theory of mind in dogs?: examining method and concept. Learning \& Behavior, 39, 314-317. doi:10.3758/s13420-011-0041-7

Horowitz, A. (2012). Fair is fine, but more is better: limits to inequity aversion in the domestic dog. Social Justice Research, 25, 195-212. doi:10.1007/s11211-012-0158-7

Horvath, Z., Doka, A. \& Miklósi, A. (2008). Affiliative and disciplinary behavior of human handlers during play with their dog affects cortisol concentrations in opposite directions. Hormones and Behavior, 54, 107-114. doi:10.1016/j.yhbeh.2008.02.002

Howell, T. J., Conduit, R., Toukhsati, S. \& Bennett, P. (2012). Auditory stimulus discrimination recorded in dogs, as indicated by mismatch negativity (MMN). Behavioural Processes, 89, 8-13. doi:10.1016/j.beproc.2011.09.009

Hsu, Y. Y. \& Serpell, J. A. (2003). Development and validation of a questionnaire for measuring behavior and temperament traits in pet dogs. Journal of the American Veterinary Medical Association, 223, 1293-1300. doi:10.2460/javma.2003.223.1293

Hydbring-Sandberg, E., von Walter, L. W., Hoglund, K., Svartberg, K., Swenson, L. \& Forkman, B. (2004). Physiological reactions to fear provocation in dogs. Journal of Endocrinology, 180, 439-448. doi:10.1677/joe.0.1800439

Imamura, Y., Terada, K. \& Takahashi, H. (2015). Effects of behavioral complexity on intention attribution to robots. Proceedings of the 3rd International Conference on Human-Agent Interaction, 65-72. New York, NY: ACM. doi:10.1145/2814940.2814949

Izard, C. E. (1992). Basic emotions, relations among emotions, and emotion-cognition relations. Psychological Review, 99, 561-565. doi:10.1037/0033-295X.99.3.561 
Jackson, P. L., Meltzoff, A. N. \& Decety, J. (2005). How do we perceive the pain of others? A window into the neural processes involved in empathy. Neuroimage, 24, 771-779. doi:10.1016/j.neuroimage.2004.09.006

Jensen, P. (2007). Mechanisms and function in dog behaviour. In P. Jensen (Ed.), The behavioural biology of dogs (pp. 61-75). Wallingford: CABI.

Jia, H., Pustovyy, O. M., Waggoner, P., Beyers, R. J., Schumacher, J., Wildey, C., Barrett, J., Morrison, E., Salibi, N., Denney, T. S., Vodyanoy, V. J. \& Deshpande, G. (2014). Functional MRI of the olfactory system in conscious dogs. Plos ONE, 9, e86362. doi:10.1371/journal.pone.0086362

Johnson, M. H., Dziurawiec, S., Ellis, H. \& Morton, J. (1991). Newborns' preferential tracking of face-like stimuli and its subsequent decline. Cognition, 40, 1-19. doi:10.1016/00100277(91)90045-6

Joly-Mascheroni, R. M., Senju, A. \& Shepherd, A. J. (2008). Dogs catch human yawns. Biology Letters, 4, 446-448. doi:10.1098/rsbl.2008.0333

Kaminski, J., Tempelmann, S., Call, J. \& Tomasello, M. (2009). Domestic dogs comprehend human communication with iconic signs. Developmental Science, 12, 831-837. doi:10.1111/j.1467-7687.2009.00815.x

Kanwisher, N., McDermott, J. \& Chun, M. M. (1997). The fusiform face area: a module in human extrastriate cortex specialized for face perception. Journal of Neuroscience, 17, 4302-4311.

Karagiannis, C. I., Burman, O. H. P. \& Mills, D. S. (2015). Dogs with separation-related problems show a "less pessimistic" cognitive bias during treatment with fluoxetine (Reconcile (TM)) and a behaviour modification plan. BMC Veterinary Research, 11, 80. doi:10.1186/s12917-015-0373-1

Kendrick, K. M. \& Baldwin, B. A. (1987). Cells in temporal cortex of conscious sheep can respond preferentially to the sight of faces. Science, 236, 448-450. doi:10.1126/science.3563521

Kiesler, S., Lee, S.-L. \& Kramer, A. D. I. (2006). Relationship effects in psychological explanations of nonhuman behavior. Anthrozoös, 19, 335-352. doi: $10.2752 / 089279306785415448$

Kiesler, T. \& Kiesler, S. (2005). My pet rock and me: an experimental exploration of the self extension concept. In G. Menon \& A. R. Rao (Eds.), Advances in consumer research (pp. 365-370). Duluth, MN: Association for Consumer Research.

King, A. S. (1987). Physiological and clinical anatomy of the domestic mammals. Volume 1: Central nervous system. Oxford: Oxford University Press.

King, T., Hemsworth, P. H. \& Coleman, G. J. (2003). Fear of novel and startling stimuli in domestic dogs. Applied Animal Behaviour Science, 82, 45-64. doi:10.1016/S01681591(03)00040-6

Kis, A., Hernadi, A., Kanizsar, O., Gácsi, M. \& Topal, J. (2015). Oxytocin induces positive expectations about ambivalent stimuli (cognitive bias) in dogs. Hormones and Behavior, 69, 1-7. doi:10.1016/j.yhbeh.2014.12.004

Kis, A., Szakadat, S., Kovacs, E., Gácsi, M., Simor, P., Gombos, F., Topal, J., Miklósi, A. \& Bodizs, R. (2014). Development of a non-invasive polysomnography technique for dogs (Canis familiaris). Physiology \& Behavior, 130, 149-156. doi:10.1016/j.physbeh.2014.04.004 
Kriegeskorte, N., Simmons, W. K., Bellgowan, P. S. \& Baker, C. I. (2009). Circular analysis in systems neuroscience: the dangers of double dipping. Nature Neuroscience, 12, 535-540. doi:10.1038/nn.2303

Kujala, M. V., Kujala, J., Carlson, S. \& Hari, R. (2012). Dog experts' brains distinguish socially relevant body postures similarly in dogs and humans. Plos ONE, 7, e39145. doi:10.1371/journal.pone.0039145

Kujala, M. V., Somppi, S., Jokela, M., Vainio, O. \& Parkkonen, L. (2017). Human empathy, personality and experience affect the emotion ratings of dog and human facial expressions. Plos ONE, 12, e0170730. doi:10.1371/journal.pone.0170730

Kujala, M. V., Törnqvist, H., Somppi, S., Hänninen, L., Krause, C. M., Vainio, O. \& Kujala, J. (2013). Reactivity of dogs' brain oscillations to visual stimuli measured with noninvasive electroencephalography. Plos ONE, 8, e61818. doi:10.1371/journal.pone.0061818

Kwan, V. S. Y., Gosling, S. D. \& John, O. P. (2008). Anthropomorphism as a special case of social perception: A cross-species social relations model analysis of humans and dogs. Social Cognition, 26, 129-142. doi:10.1521/soco.2008.26.2.129

Lakestani, N. N., Donaldson, M. \& Waran, N. (2014). Interpretation of dog behaviour by children and young adults. Anthrozoös, 27, 65-80. doi:10.2752/175303714x13837396326413

Lawrence, E. J., Shaw, P., Baker, D., Baron-Cohen, S. \& David, A. S. (2004). Measuring empathy: reliability and validity of the Empathy Quotient. Psychological Medicine, 34, 911-919. doi:10.1017/S0033291703001624

Leary, M. R. (2003). The self and emotion: the role of self-reflection in the generation and regulation of affective experience. In R. J. Davidson, K. R. Scherer \& H. H. Goldsmith (Eds.), Handbook of affective sciences (pp. 773-786). New York: Oxford University Press.

Lempers, J. D., Flavell, E. R. \& Flavell, J. H. (1977). Development in very young children of tacit knowledge concerning visual perception. Genetic Psychology Monographs, 95, 3-53.

Leopold, D. A. \& Rhodes, G. (2010). A comparative view of face perception. Journal of Comparative Psychology, 124, 233-251. doi:10.1037/a0019460

Leppänen, J. M. \& Nelson, C. A. (2009). Tuning the developing brain to social signals of emotions. Nature Reviews Neuroscience, 10, 37-47. doi:10.1038/nrn2554

Leyens, J.-P., Paladino, P. M., Rodriguez-Torres, R., Vaes, J., Demoulin, S., Rodriguez-Perez, A. \& Gaunt, R. (2000). The emotional side of prejudice: the attribution of secondary emotions to ingroups and outgroups. Personality and Social Psychology Review, 4, 186197. doi:10.1207/S15327957PSPR0402_06

MacLeod, A. K. \& Byrne, A. (1996). Anxiety, depression, and the anticipation of future positive and negative experiences. Journal of Abnormal Psychology, 105, 286-289. doi:10.1037/0021-843x.105.2.286

Madsen, E. A. \& Persson, T. (2013). Contagious yawning in domestic dog puppies (Canis lupus familiaris): the effect of ontogeny and emotional closeness on low-level imitation in dogs. Animal Cognition, 16, 233-240. doi:10.1007/s10071-012-0568-9

Martini, M. C., Gonzalez, C. A. \& Wiese, E. (2016). Seeing minds in others: can agents with robotic appearance have human-like preferences? Plos ONE, 11, e0146310. doi:10.1371/journal.pone.0146310 
Masserman, J. H., Wechkin, S. \& Terris, W. (1964). "Altruistic" behavior in rhesus monkeys. The American Journal of Psychiatry, 121, 584-585. doi:10.1176/ajp.121.6.584

McGreevy, P. D., Georgevsky, D., Carrasco, J., Valenzuela, M., Duffy, D. L. \& Serpell, J. A. (2013). Dog behavior co-varies with height, bodyweight and skull shape. Plos ONE, 8, e80529. doi:10.1371/journal.pone.0080529

McGreevy, P., Grassi, T. D. \& Harman, A. M. (2004). A strong correlation exists between the distribution of retinal ganglion cells and nose length in the dog. Brain, Behavior and Evolution, 63, 13-22. doi:10.1159/000073756

Mehrabian, A. \& Epstein, N. (1972). Measure of emotional empathy. Journal of Personality, 40, 525-543. doi:10.1111/j.1467-6494.1972.tb00078.x

Mehrkam, L. R. \& Wynne, C. D. L. (2014). Behavioral differences among breeds of domestic dogs (Canis lupus familiaris): current status of the science. Applied Animal Behaviour Science, 155, 12-27. doi:10.1016/j.applanim.2014.03.005

Meints, K., Racca, A. \& Hickey, N. (2010). How to prevent dog bite injuries? Children misinterpret dogs facial expressions. Injury Prevention, 16, A68. doi:10.1136/ip.2010.029215.0246

Melzack, R. (1952). Irrational fears in the dog. Canadian Journal of Psychology, 6, 141-147. doi:10.1037/H0083562

Melzack, R. (1954). The genesis of emotional behavior; an experimental study of the dog. Journal of Comparative and Physiological Psychology, 47, 166-168. doi:10.1037/h0055840

Mendl, M., Brooks, J., Basse, C., Burman, O., Paul, E., Blackwell, E. \& Casey, R. (2010a). Dogs showing separation-related behaviour exhibit a 'pessimistic' cognitive bias. Current Biology, 20, R839-R840. doi:10.1016/j.cub.2010.08.030

Mendl, M., Burman, O. H. \& Paul, E. S. (2010b). An integrative and functional framework for the study of animal emotion and mood. Proceedings of the Royal Society B: Biological Sciences, 277, 2895-2904. doi:10.1098/rspb.2010.0303

Merola, I., Prato-Previde, E. \& Marshall-Pescini, S. (2012a). Dogs' social referencing towards guardians and strangers. Plos ONE, 7, e47653. doi:10.1371/journal.pone.0047653

Merola, I., Prato-Previde, E. \& Marshall-Pescini, S. (2012b). Social referencing in dogguardian dyads? Animal Cognition, 15, 175-185. doi:10.1007/s10071-011-0443-0

Merola, I., Prato-Previde, E., Lazzaroni, M. \& Marshall-Pescini, S. (2014). Dogs' comprehension of referential emotional expressions: familiar people and familiar emotions are easier. Animal Cognition, 17, 373-385. doi:10.1007/s10071-013-0668-1

Meyer, I. \& Forkman, B. (2014). Nonverbal communication and human-dog interaction. Anthrozoös, 27, 553-568. doi:10.2752/089279314x14072268687925

Meyer, I., Forkman, B. \& Paul, E. S. (2014). Factors affecting the human interpretation of dog behavior. Anthrozoös, 27, 127-140. doi:10.2752/175303714x13837396326576

Miklósi, A., Kubinyi, E., Topal, J., Gácsi, M., Viranyi, Z. \& Csanyi, V. (2003). A simple reason for a big difference: wolves do not look back at humans, but dogs do. Current Biology, 13, 763-766. doi:10.1016/S0960-9822(03)00263-X

Miller, S. C., Kennedy, C., Devoe, D., Hickey, M., Nelson, T. \& Kogan, L. (2009). An examination of changes in oxytocin levels in men and women before and after interaction with a bonded dog. Anthrozoös, 22, 31-42. doi:10.2752/175303708x390455 
Mirkó, E., Doká, A. \& Miklósi, A. (2013). Association between subjective rating and behaviour coding and the role of experience in making video assessments on the personality of the domestic dog (Canis familiaris). Applied Animal Behaviour Science, 149, 45-54. doi:10.1016/j.applanim.2013.10.003

Moll, J., de Oliveira-Souza, R., Bramati, I. E. \& Grafman, J. (2002). Functional networks in emotional moral and nonmoral social judgments. Neuroimage, 16, 696-703. doi:S1053811902911183

Morris, P. H., Doe, C. \& Godsell, E. (2008). Secondary emotions in non-primate species? Behavioural reports and subjective claims by animal guardians. Cognition and Emotion, 22, 3-20. doi:10.1080/02699930701273716

Morris, P. H., Knight, S. \& Lesley, S. (2012). Belief in animal mind: Does familiarity with animals influence beliefs about animal emotions? Society \& Animals, 20, 211-224. doi:10.1163/15685306-12341234

Morrow, M., Ottobre, J., Ottobre, A., Neville, P., St-Pierre, N., Dreschel, N. \& Pate, J. L. (2015). Breed-dependent differences in the onset of fear-related avoidance behavior in puppies. Journal of Veterinary Behavior-Clinical Applications and Research, 10, 286-294. doi:10.1016/j.jveb.2015.03.002

Müller, C. A., Riemer, S., Rosam, C. M., Schosswender, J., Range, F. \& Huber, L. (2012). Brief guardian absence does not induce negative judgement bias in pet dogs. Animal Cognition, 15, 1031-1035. doi:10.1007/s10071-012-0526-6

Müller, C. A., Schmitt, K., Barber, A. L. \& Huber, L. (2015). Dogs can discriminate emotional expressions of human faces. Current Biology, 25, 601-605. doi:10.1016/j.cub.2014.12.055

Nagasawa, M., Kikusui, T., Onaka, T. \& Ohta, M. (2009). Dog's gaze at its guardian increases guardian's urinary oxytocin during social interaction. Hormones and Behavior, 55, 434441. doi:10.1016/j.yhbeh.2008.12.002

Nagasawa, M., Mitsui, S., En, S., Ohtani, N., Ohta, M., Sakuma, Y., Onaka, T., Mogi, K. \& Kikusui, T. (2015). Social evolution. Oxytocin-gaze positive loop and the coevolution of humandog bonds. Science, 348, 333-336. doi:10.1126/science.1261022

Nagasawa, M., Murai, K., Mogi, K. \& Kikusui, T. (2011). Dogs can discriminate human smiling faces from blank expressions. Animal Cognition, 14, 525-533. doi:10.1007/s10071-0110386-5

Nagel, T. (1974). What is it like to be a bat? The Philosophical Review, 83, 435-450. doi:10.2307/2183914

Nass, C., Steuer, J. \& Tauber, E. (1994). Computers are social actors. Proceedings of the Conference on Human Factors in Computing Systems CHI '94, 72-78. New York, NY: ACM. doi:10.1145/191666.191703

Netto, W. J. \& Planta, D. J. U. (1997). Behavioural testing for aggression in the domestic dog. Applied Animal Behaviour Science, 52, 243-263. doi:10.1016/S0168-1591(96)01126-4

Norring, M., Wikman, I., Hokkanen, A. H., Kujala, M. V. \& Hänninen, L. (2014). Empathic veterinarians score cattle pain higher. The Veterinary Journal, 200, 186-190. doi:10.1016/j.tvjl.2014.02.005

O'Hara, S. J. \& Reeve, A. V. (2011). A test of the yawning contagion and emotional connectedness hypothesis in dogs, Canis familiaris. Animal Behaviour, 81, 335-340. doi:10.1016/j.anbehav.2010.11.005 
Odendaal, J. S. J. \& Meintjes, R. A. (2003). Neurophysiological correlates of affiliative behaviour between humans and dogs. The Veterinary Journal, 165, 296-301. doi:10.1016/S1090-0233(02)00237-X

Ogata, N., Kikusui, T., Takeuchi, Y. \& Mori, Y. (2006). Objective measurement of fearassociated learning in dogs. Journal of Veterinary Behavior-Clinical Applications and Research, 1, 55-61. doi:10.1016/j.jveb.2006.06.002

Overall, K. L. (2000). Natural animal models of human psychiatric conditions: assessment of mechanism and validity. Progress in Neuro-Psychopharmacology \& Biological Psychiatry, 24, 727-776. doi:10.1016/S0278-5846(00)00104-4

Palagi, E. \& Cordoni, G. (2009). Postconflict third-party affiliation in Canis lupus: Do wolves share similarities with the great apes? Animal Behaviour, 78, 979-986. doi:10.1016/j.anbehav.2009.07.017

Palagi, E., Nicotra, V. \& Cordoni, G. (2015). Rapid mimicry and emotional contagion in domestic dogs. Royal Society Open Science, 2, 150505. doi:10.1098/rsos.150505

Palazzi, X. (2011). The beagle brain in stereotaxic coordinates. New York: Springer

Panksepp, J. (1998). Affective neuroscience: The foundations of human and animal emotions. Oxford: Oxford University Press

Parr, L. A., Waller, B. M., Burrows, A. M., Gothard, K. M. \& Vick, S. J. (2010). MaqFACS: a muscle-based facial movement coding system for the macaque monkey. American Journal of Physical Anthropology, 143, 625-630. doi:10.1002/ajpa.21401

Paul, E. S. (2000). Empathy with animals and with humans: are they linked? Anthrozoös, 13, 194-202. doi:10.2752/089279300786999699

Plutchik, R. (2001). The nature of emotions. American Scientist, 89, 344-350. doi:10.1511/2001.4.344

Poldrack, R. A. \& Mumford, J. A. (2009). Independence in ROI analysis: where is the voodoo? Social Cognitive and Affective Neuroscience, 4, 208-213. doi:10.1093/scan/nsp011

Pongrácz, P., Molnar, C., Miklósi, A. \& Csanyi, V. (2005). Human listeners are able to classify dog (Canis familiaris) barks recorded in different situations. Journal of Comparative Psychology, 119, 136-144. doi:10.1037/0735-7036.119.2.136

Preston, S. D. \& de Waal, F. B. (2002). Empathy: its ultimate and proximate bases. Behavioral and Brain Sciences, 25, 1-20; discussion 20-71. doi:10.1017/S0140525X02000018

Quervel-Chaumette, M., Dale, R., Marshall-Pescini, S. \& Range, F. (2015). Familiarity affects other-regarding preferences in pet dogs. Scientific Reports, 5, 18102. doi:10.1038/srep18102

Quervel-Chaumette, M., Faerber, V., Faragó, T., Marshall-Pescini, S. \& Range, F. (2016). Investigating empathy-like responding to conspecifics' distress in pet dogs. Plos ONE, 11, e0152920. doi:10.1371/journal.pone.0152920

Quinn, P. C., Doran, M. M., Reiss, J. E. \& Hoffman, J. E. (2009). Time course of visual attention in infant categorization of cats versus dogs: evidence for a head bias as revealed through eye tracking. Child Development, 80, 151-161. doi:10.1111/j.1467-8624.2008.01251.x

Racca, A., Guo, K., Meints, K. \& Mills, D. S. (2012). Reading faces: differential lateral gaze bias in processing canine and human facial expressions in dogs and 4-year-old children. Plos ONE, 7, e36076. doi:10.1371/journal.pone.0036076 
Range, F. \& Viranyi, Z. (2014). Tracking the evolutionary origins of dog-human cooperation: the "Canine Cooperation Hypothesis". Frontiers in Psychology, 5, 1582. doi:10.3389/fpsyg.2014.01582

Range, F., Horn, L., Viranyi, Z. \& Huber, L. (2009). The absence of reward induces inequity aversion in dogs. Proceedings of the National Academy of Sciences of the United States of America, 106, 340-345. doi:10.1073/pnas.0810957105

Range, F., Leitner, K. \& Virányi, Z. (2012). The influence of the relationship and motivation on inequity aversion in dogs. Social Justice Research, 25, 170-194. doi:10.1007/s11211012-0155-x

Range, F., Ritter, C. \& Viranyi, Z. (2015). Testing the myth: tolerant dogs and aggressive wolves. Proceedings of the Royal Society B: Biological Sciences, 282, 20150220. doi:10.1098/rspb.2015.0220

Reisner, I. R. (1997). Assessment, management, and prognosis of canine dominance-related aggression. Veterinary Clinics of North America-Small Animal Practice, 27, 479-495. doi:10.1016/S0195-5616(97)50050-7

Reisner, I. R., Mann, J. J., Stanley, M., Huang, Y. Y. \& Houpt, K. A. (1996). Comparison of cerebrospinal fluid monoamine metabolite levels in dominant-aggressive and nonaggressive dogs. Brain Research, 714, 57-64. doi:10.1016/0006-8993(95)01464-0

Rice, G. E. \& Gainer, P. (1962). "Altruism" in the albino rat. Journal of Comparative and Physiological Psychology, 55, 123-125. doi:10.3758/BF03336420

Riemer, S., Assis, L., Pike, T. W. \& Mills, D. S. (2016). Dynamic changes in ear temperature in relation to separation distress in dogs. Physiology \& Behavior, 167, 86-91. doi:10.1016/j.physbeh.2016.09.002

Roberts, T., McGreevy, P. \& Valenzuela, M. (2010). Human induced rotation and reorganization of the brain of domestic dogs. Plos ONE, 5, e11946. doi:10.1371/journal.pone.0011946

Roberts, W. \& Strayer, J. (1996). Empathy, emotional expressiveness, and prosocial behavior. Child Development, 67, 449-470. doi:10.1111/j.1467-8624.1996.tb01745.x

Romero, T., Ito, M., Saito, A. \& Hasegawa, T. (2014). Social modulation of contagious yawning in wolves. Plos ONE, 9, e105963. doi:10.1371/journal.pone.0105963

Romero, T., Konno, A. \& Hasegawa, T. (2013). Familiarity bias and physiological responses in contagious yawning by dogs support link to empathy. Plos ONE, 8, e71365. doi:10.1371/journal.pone.0071365

Rooney, N. J., Bradshaw, J. W. S. \& Robinson, I. H. (2000). A comparison of dog-dog and doghuman play behaviour. Applied Animal Behaviour Science, 66, 235-248. doi:10.1016/S0168-1591(99)00078-7

Rygula, R., Szczech, E., Kregiel, J., Golebiowska, J., Kubik, J. \& Popik, P. (2015). Cognitive judgment bias in the psychostimulant-induced model of mania in rats.

Psychopharmacology, 232, 651-660. doi:10.1007/s00213-014-3707-y

Saarela, M. V., Hlushchuk, Y., Williams, A. C., Schurmann, M., Kalso, E. \& Hari, R. (2007). The compassionate brain: humans detect intensity of pain from another's face. Cerebral Cortex, 17, 230-237. doi:10.1093/cercor/bhj141

Schilbach, L., Timmermans, B., Reddy, V., Costall, A., Bente, G., Schlicht, T. \& Vogeley, K. (2013). Toward a second-person neuroscience. Behavioral and Brain Sciences, 36, 393414. doi:10.1017/S0140525X12000660 
Schirmer, A., Seow, C. S. \& Penney, T. B. (2013). Humans process dog and human facial affect in similar ways. Plos ONE, 8, e74591. doi:10.1371/journal.pone.0074591

Scholl, B. J. \& Tremoulet, P. D. (2000). Perceptual causality and animacy. Trends in Cognitive Sciences, 4, 299-309. doi:10.1016/S1364-6613(00)01506-0

Schürmann, M., Hesse, M. D., Stephan, K. E., Saarela, M., Zilles, K., Hari, R. \& Fink, G. R. (2005). Yearning to yawn: the neural basis of contagious yawning. Neuroimage, 24, 1260-1264. doi:10.1016/j.neuroimage.2004.10.022

Scott, J. P. \& Fuller, J. L. (1965). Genetics and the social behavior of the dog. Chicago, IL: The University of Chicago Press.

Senju, A., Kikuchi, Y., Akechi, H., Hasegawa, T., Tojo, Y. \& Osanai, H. (2009). Brief report: does eye contact induce contagious yawning in children with autism spectrum disorder? Journal of Autism and Developmental Disorders, 39, 1598-1602. doi:10.1007/s10803009-0785-5

Senju, A., Maeda, M., Kikuchi, Y., Hasegawa, T., Tojo, Y. \& Osanai, H. (2007). Absence of contagious yawning in children with autism spectrum disorder. Biology Letters, 3, 706708. doi:10.1098/rsbl.2007.0337

Sforzini, E., Michelazzi, M., Spada, E., Ricci, C., Carenzi, C., Milani, S., Luzi, F. \& Verga, M. (2009). Evaluation of young and adult dogs' reactivity. Journal of Veterinary BehaviorClinical Applications and Research, 4, 3-10. doi:10.1016/j.jveb.2008.09.035

Shaver, P. R., Wu, S. \& Schwartz, J. C. (1992). Cross-cultural similarities and differences in emotion and its representation: a prototype approach. In M. S. Clark (Ed.), Emotion (pp. 175-212). Thousand Oaks, CA: Sage Publications, Inc.

Sherman, B. L. \& Mills, D. S. (2008). Canine anxieties and phobias: an update on separation anxiety and noise aversions. Veterinary Clinics of North America-Small Animal Practice, 38, 1081-1106. doi:10.1016/j.cvsm.2008.04.012

Silva, K. \& de Sousa, L. (2011). 'Canis empathicus'? A proposal on dogs' capacity to empathize with humans. Biology Letters, 7, 489-492. doi:10.1098/rsbl.2011.0083

Silva, K., Bessa, J. \& de Sousa, L. (2012). Auditory contagious yawning in domestic dogs (Canis familiaris): first evidence for social modulation. Animal Cognition, 15, 721-724. doi:10.1007/s10071-012-0473-2

Silva, K., Bessa, J. \& de Sousa, L. (2013). Familiarity-connected or stress-based contagious yawning in domestic dogs (Canis familiaris)? Some additional data. Animal Cognition, 16, 1007-1009. doi:10.1007/s10071-013-0669-0

Singer, T., Seymour, B., O'Doherty, J., Kaube, H., Dolan, R. J. \& Frith, C. D. (2004). Empathy for pain involves the affective but not sensory components of pain. Science, 303, 1157-1162. doi:10.1126/science.1093535

Sjaastad, O. V., Sand, O. \& Hove, K. (2010). Physiology of domestic animals. Oslo, Norway: Scandinavian Veterinary Press.

Somppi, S., Törnqvist, H., Kujala, M. V., Hänninen, L., Krause, C. M. \& Vainio, O. (2016). Dogs evaluate threatening facial expressions by their biological validity: evidence from gazing patterns. Plos One, 11, e0143047. doi:10.1371/journal.pone.0143047

Soproni, K., Miklósi, A., Topal, J. \& Csanyi, V. (2001). Comprehension of human communicative signs in pet dogs (Canis familiaris). Journal of Comparative Psychology, 115, 122-126. doi:10.1037/0735-7036.115.2.122 
Spunt, R. P., Ellsworth, E. \& Adolphs, R. (2016). The neural basis of understanding the expression of the emotions in man and animals. Social Cognitive and Affective Neuroscience. doi:10.1093/scan/nsw161

Tami, G. \& Gallagher, A. (2009). Description of the behaviour of domestic dog (Canis familiaris) by experienced and inexperienced people. Applied Animal Behaviour Science, 120, 159-169. doi:10.1016/j.applanim.2009.06.009

Tate, A. J., Fischer, H., Leigh, A. E. \& Kendrick, K. M. (2006). Behavioural and neurophysiological evidence for face identity and face emotion processing in animals. Philosophical Transactions of the Royal Society B: Biological Sciences, 361, 2155-2172. doi:10.1098/rstb.2006.1937

Taylor, N. \& Signal, T. D. (2005). Empathy and attitudes to animals. Anthrozoös, 18, 18-27. doi:10.2752/089279305785594342

Tomarken, A. J., Davidson, R. J., Wheeler, R. E. \& Doss, R. C. (1992). Individual differences in anterior brain asymmetry and fundamental dimensions of emotion. Journal of Personality and Social Psychology, 62, 676-687. doi:10.1037/0022-3514.62.4.676

Törnqvist, H., Kujala, M. V., Somppi, S., Hänninen, L., Pastell, M., Krause, C. M., Kujala, J. \& Vainio, 0. (2013). Visual event-related potentials of dogs: a non-invasive electroencephalography study. Animal Cognition, 16, 973-982. doi:10.1007/s10071013-0630-2

Törnqvist, H., Somppi, S., Koskela, A., Krause, C. M., Vainio, O. \& Kujala, M. V. (2015). Comparison of dogs and humans in visual scanning of social interaction. Royal Society Open Science, 2, 150341. doi:10.1098/rsos.150341

Torres-Pereira, C. M. C. \& Broom, D. M. (2014). Does dog behaviour and physiology after doing wrong indicate guilt, shame or fear? Vitoria-Gasteiz, Spain: Wageningen Academic Publishers.

Travain, T., Colombo, E. S., Grandi, L. C., Heinzl, E., Pelosi, A., Prato Previde, E. \& Valsecchi, P. (2016). How good is this food? A study on dogs' emotional responses to a potentially pleasant event using infrared thermography. Physiology \& Behavior, 159, 80-87. doi:10.1016/j.physbeh.2016.03.019

Travain, T., Colombo, E. S., Heinzl, E., Bellucci, D., Prato Previde, E. \& Valsecchi, P. (2015). Hot dogs: thermography in the assessment of stress in dogs (Canis familiaris) - a pilot study. Journal of Veterinary Behavior: Clinical Applications and Research, 10, 17-23. doi:10.1016/j.jveb.2014.11.003

Trut, L. N. (2001). Experimental studies of early canid domestication. In A. Ruvinsky \& J. Sampson (Eds.), The genetics of the dog (pp. 15-42). New York: CABI Publishing. Turcsán, B., Szánthó, F., Miklósi, A. \& Kubinyi, E. (2015). Fetching what the guardian prefers? Dogs recognize disgust and happiness in human behaviour. Animal Cognition, 18, 83-94. doi:10.1007/s10071-014-0779-3

Tversky, A. \& Kahneman, D. (1974). Judgment under uncertainty: heuristics and biases. Science, 185, 1124-1131. doi:10.1126/science.185.4157.1124

Urquiza-Haas, E. G. \& Kotrschal, K. (2015). The mind behind anthropomorphic thinking: attribution of mental states to other species. Animal Behaviour, 109, 167-176. doi:10.1016/j.anbehav.2015.08.011 
Usui, S., Senju, A., Kikuchi, Y., Akechi, H., Tojo, Y., Osanai, H. \& Hasegawa, T. (2013). Presence of contagious yawning in children with autism spectrum disorder. Autism Research and Treatment, 2013, 971686. doi:10.1155/2013/971686

Vaes, J., Meconi, F., Sessa, P. \& Olechowski, M. (2016). Minimal humanity cues induce neural empathic reactions towards non-human entities. Neuropsychologia, 89, 132-140. doi:10.1016/j.neuropsychologia.2016.06.004

van den Berg, L., Schilder, M. B. H. \& Knol, B. W. (2003). Behavior genetics of canine aggression: behavioral phenotyping of golden retrievers by means of an aggression test. Behavior Genetics, 33, 469-483. doi:10.1023/A:1025714431089

van der Borg, J. A. M., Beerda, B., Ooms, M., de Souza, A. S., van Hagen, M. \& Kemp, B. (2010). Evaluation of behaviour testing for human directed aggression in dogs. Applied Animal Behaviour Science, 128, 78-90. doi:10.1016/j.applanim.2010.09.016

van der Borg, J. A. M., Netto, W. J. \& Planta, D. J. U. (1991). Behavioral-testing of dogs in animal shelters to predict problem behavior. Applied Animal Behaviour Science, 32, 237251. doi:10.1016/S0168-1591(05)80047-4

Vick, S. J., Waller, B. M., Parr, L. A., Smith Pasqualini, M. C. \& Bard, K. A. (2007). A crossspecies comparison of facial morphology and movement in humans and chimpanzees using the Facial Action Coding System (FACS). Journal of Nonverbal Behavior, 31, 1-20. doi:10.1007/s10919-006-0017-z

Vul, E., Harris, C., Winkielman, P. \& Pashler, H. (2009). Puzzlingly high correlations in fMRI studies of emotion, personality, and social cognition. Perspectives on Psychological Science, 4, 274-290. doi:10.1111/j.1745-6924.2009.01125.x

Walker, J. K., McGrath, N., Handel, I. G., Waran, N. K. \& Phillips, C. J. C. (2014). Does owning a companion animal influence the belief that animals experience emotions such as grief? Animal Welfare, 23, 71-79. doi:10.7120/09627286.23.1.071

Walker, J., Dale, A., Waran, N., Clarke, N., Farnworth, M. \& Wemelsfelder, F. (2010). The assessment of emotional expression in dogs using a Free Choice Profiling methodology. Animal Welfare, 19, 75-84.

Waller, B. M., Kuchenbuch, P., Lembeck, M., Burrows, A. M. \& Liebal, K. (2012). GibbonFACS: a muscle based coding system for the hylobatids. International Journal of Primatology, 33, 809-821. doi:10.1007/s10764-012-9611-6

Waller, B. M., Peirce, K., Caeiro, C. C., Scheider, L., Burrows, A. M., McCune, S. \& Kaminski, J. (2013). Paedomorphic facial expressions give dogs a selective advantage. Plos ONE, 8, e82686. doi:10.1371/journal.pone.0082686

Wan, M., Bolger, N. \& Champagne, F. A. (2012). Human perception of fear in dogs varies according to experience with dogs. Plos ONE, 7, e51775. doi:10.1371/journal.pone.0051775

Ward, C., Bauer, E. B. \& Smuts, B. B. (2008). Partner preferences and asymmetries in social play among domestic dog, Canis lupus familiaris, littermates. Animal Behaviour, 76, 1187-1199. doi:10.1016/j.anbehav.2008.06.004

Watanabe, S. \& Ono, K. (1986). An experimental analysis of "empathic" response: effects of pain reactions of pigeon upon other pigeon's operant behavior. Behavioural Processes, 13, 269-277. doi:10.1016/0376-6357(86)90089-6

Wathan, J., Burrows, A. M., Waller, B. M. \& McComb, K. (2015). EquiFACS: the Equine Facial Action Coding System. Plos ONE, 10, e0131738. doi:10.1371/journal.pone.0131738 
Westbury Ingham, H. R., Neumann, D. \& Waters, A. (2015). Empathy-related ratings to still images of human and nonhuman animal groups in negative contexts graded for phylogenetic similarity. Anthrozoös, 28, 113-130. doi:10.2752/089279315x14129350722136

Whalen, P. J. (1998). Fear, vigilance, and ambiguity: initial neuroimaging studies of the human amygdala. Current Directions in Psychological Science, 7, 177-188. doi:10.1111/1467-8721.ep10836912

Wright, J. C. \& Nesselrote, M. S. (1987). Classification of behavior problems in dogs: distributions of age, breed, sex and reproductive status. Applied Animal Behaviour Science, 19, 169-178. doi:10.1016/0168-1591(87)90213-9

Wright, W. F. \& Bower, G. H. (1992). Mood effects on subjective-probability assessment. Organizational Behavior and Human Decision Processes, 52, 276-291. doi:10.1016/07495978(92)90039-A

Yong, M. H. \& Ruffman, T. (2014). Emotional contagion: dogs and humans show a similar physiological response to human infant crying. Behavioural Processes, 108, 155-165. doi:10.1016/j.beproc.2014.10.006

Yong, M. H. \& Ruffman, T. (2016). Domestic dogs and human infants look more at happy and angry faces than sad faces. Multisensory Research, 29, 749-771. doi: 10.1163/2213480800002535

Call for Commentary: Animal Sentience publishes Open Peer Commentary on all accepted target articles. Target articles are peer-reviewed. Commentaries are editorially reviewed. There are submitted commentaries as well as invited commentaries. Commentaries appear as soon as they have been reviewed, revised and accepted. Target article authors may respond to their commentaries individually or in a joint response to multiple commentaries.

Instructions: http://animalstudiesrepository.org/animsent/guidelines.html 


\section{UQÀM/ISC Cognitive Science Summer School June 26 - July 6 2018, Montreal, Canada The Other Minds Problem: Animal Sentience and Cognition}

Overview. Since Descartes, philosophers know there is no way to know for sure what - or whether - others feel (not even if they tell you). Science, however, is not about certainty but about probability and evidence. The 7.5 billion individual members of the human species can tell us what they are feeling. But there are 9 million other species on the planet (20 quintillion individuals), from elephants to jellyfish, with which humans share biological and cognitive ancestry, but not one other species can speak: Which of them can feel - and what do they feel? Their human spokespersons - the comparative psychologists, ethologists, evolutionists, and cognitive neurobiologists who are the world's leading experts in "mind-reading" other species - will provide a sweeping panorama of what it feels like to be an elephant, ape, whale, cow, pig, dog, bat, chicken, fish, lizard, lobster, snail: This growing body of facts about nonhuman sentience has profound implications not only for our understanding of human cognition, but for our treatment of other sentient species.

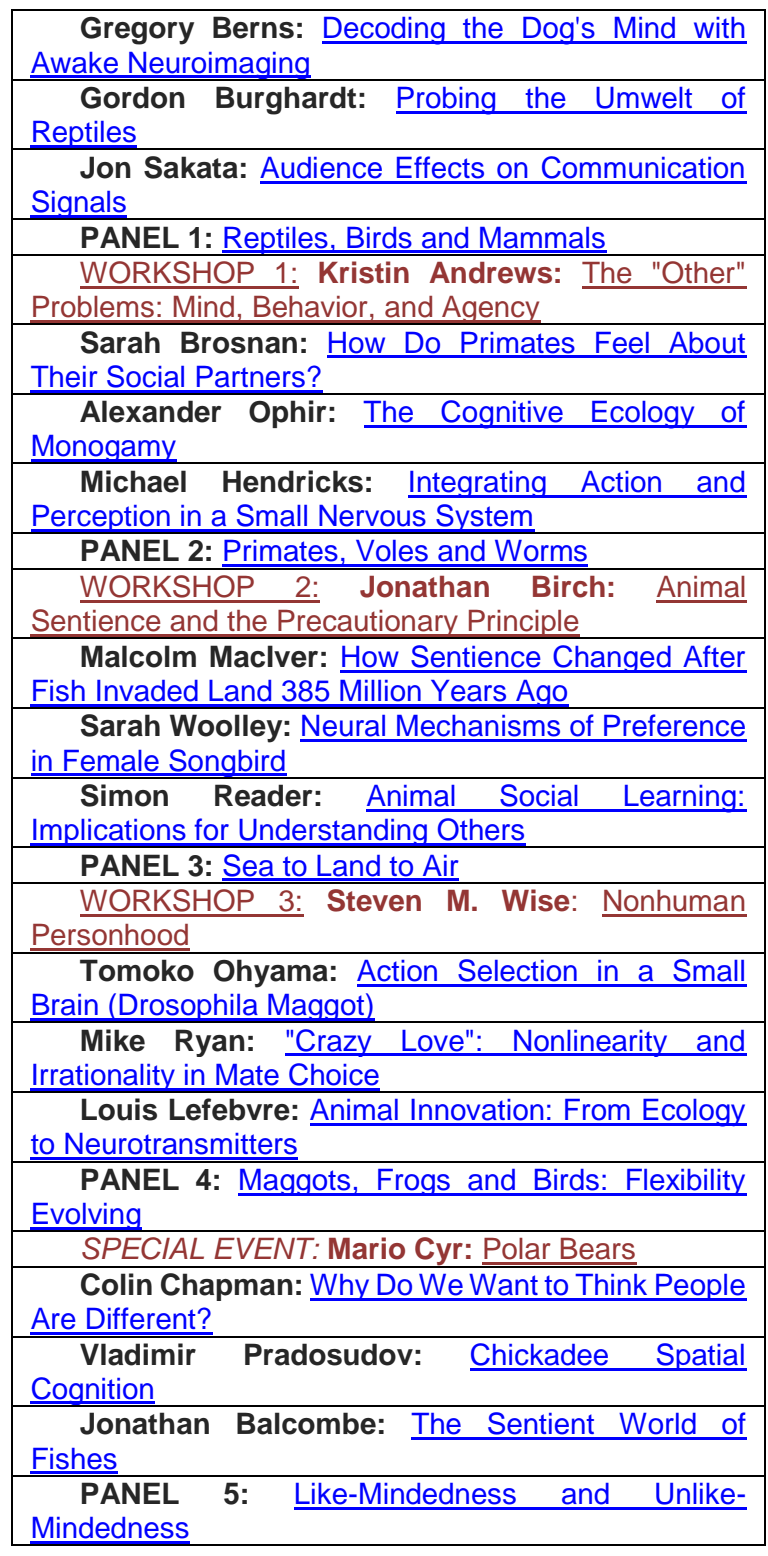

WORKSHOP 5 (part 1): Gary Comstock: $\underline{\text { A Cow's }}$ Concept of Her Future WORKSHOP 5 (part 2): Jean-Jacques KonaBoun: Physical and Mental Risks to Cattle and Horses in Rodeos

Joshua Plotnik: Thoughtful Trunks: Application of Elephant Cognition for Elephant Conservation Lori Marino: Who Are Dolphins? PANEL 6: Mammals All, Great and Small Larry Young: The Neurobiology of Social Bonding, Empathy and Social Loss in Monogamous Voles WORKSHOP 6: Lori Marino: The Inconvenient Truth About Thinking Chickens

Andrew Adamatzky: Slime Mould: Cognition Through Computation

Frantisek Baluska \& Stefano Mancuso: What a Plant Knows and Perceives Arthur Reber: A Novel Theory of the Origin of Mind: Conversations With a Caterpillar and a Bacterium PANEL 7: Microbes, Molds and Plants WORKSHOP 7: Suzanne Held \& Michael Mendl: Pig Cognition and Why It Matters James Simmons: What Is It Like To Be A Bat? Debbie Kelly: Spatial Cognition in Food-Storing Steve Phelps: Social Cognition Across Species PANEL 8: Social Space WORKSHOP 8: To be announced Lars Chittka: The Mind of the Bee Reuven Dukas: Insect Emotions: Mechanisms and Evolutionary Biology

Adam Shriver: Do Human Lesion Studies Tell Us the Cortex is Required for Pain Experiences? PANEL 9: The Invertebrate Mind WORKSHOP 9: Delcianna Winders: Nonhuman Animals in Sport and Entertainment Carel ten Cate: Avian Capacity for Categorization and Abstraction Jennifer Mather: Do Squid Have a Sense of Self? Steve Chang: Neurobiology of Monkeys Thinking About Other Monkeys PANEL 10: Others in Mind WORKSHOP 10: The Legal Status of Sentient Nonhuman Species 